\title{
Peertechz
}

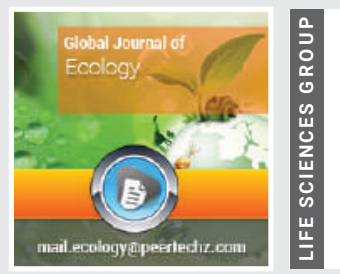

\section{Why Reforming foreign Aid is Critical to the Future of Africa, Africans \& Their Wildlife}

Received: 28 September, 2020

Accepted: 05 November, 2020

Published: 09 November, 2020

*Corresponding author: Paul Andre DeGeorges, Department of Nature Conservation, Tshwane University of Technology, Pretoria, South Africa,

E-mail: andredeg@verizon.net

https://www.peertechz.com

\section{Check for updates}

\section{Paul Andre DeGeorges ${ }^{1}$}

Retired, Department of Nature Conservation, Tshwane University of Technology, Pretoria, South Africa

\section{Abstract}

The following is a policy document based upon 30 years being involved in Sub-Saharan African conservation, advising African Governments, the U.S. Government and the hunting/conservation communities on the major issues holding back the economic development of the region and ultimately the future of its much revered megafauna. Ultimately, to save Africa's wildlife, we must provide a viable future for the people living with the wildlife. Currently, this is not the case. The current situation is explained with accompanying photographs that support these observations. Foreign aid as currently practiced has failed to achieve these goals. Reasons for this failure are discussed and recommendations made so that foreign aid can play a major role in changing the face of Africa by giving its people and in turn their wildlife a viable future.

\section{Introduction}

I spent a good part of 30 years hunting, fishing and diving from West to East Africa and down to South Africa. I have seen what many project could happen across the sub-continent unless drastic measures/changes take place - in Senegal where most of the wildlife habitat has been converted into peanut fields to provide cooking oil for the Mother Country (France) (Figure 1) or converted into sorghum and millet fields by an ever-growing population stuck in subsistence lifestyles (Figure 2) - having to drive 2-3 days to find a pocket of mega-fauna. My Father was a Pied-Noir ${ }^{2}$, and I have always had an affinity for Africa, its people and their wildlife. The following explains the author's observations and attempts to lay out possible solutions that may help Sub-Saharan Africa in conservation and development, both of which are struggling to move forward.

\section{Material and methods}

This is a policy document and in simple terms takes the author's experiences with details brought out in references
${ }^{1} 2201$ Mayflower Drive, Greenbackville, Virginia 23356, email: andredeg@verizon. net. Retired, Department of Nature Conservation, Tshwane University of Technology, Pretoria, South Africa.

${ }^{2}$ People of European, mostly French, origin who were born in Algeria during the period of French rule from 1830 to 1962. provided by this paper that can be downloaded on ResearchGate under his name, Andre DeGeorges.

\section{Results and discussion}

\section{Why conservation on its own Fails}

One thing that bothers me from what I have experienced is what I call "Blind Flag Waving Conservation", as though conservation in Africa is the end all, the savior of wildlife and

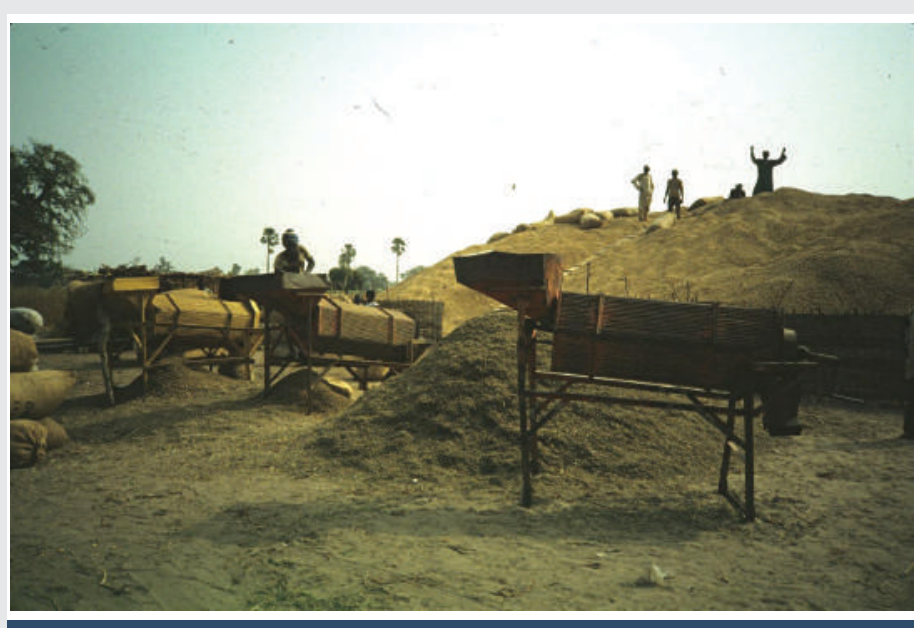

Figure 1: A Mountain of Peanuts providing cooking oil for the Mother Country (France), while displacing wildlife, Senegal 1980s. Source Photo [1]. 


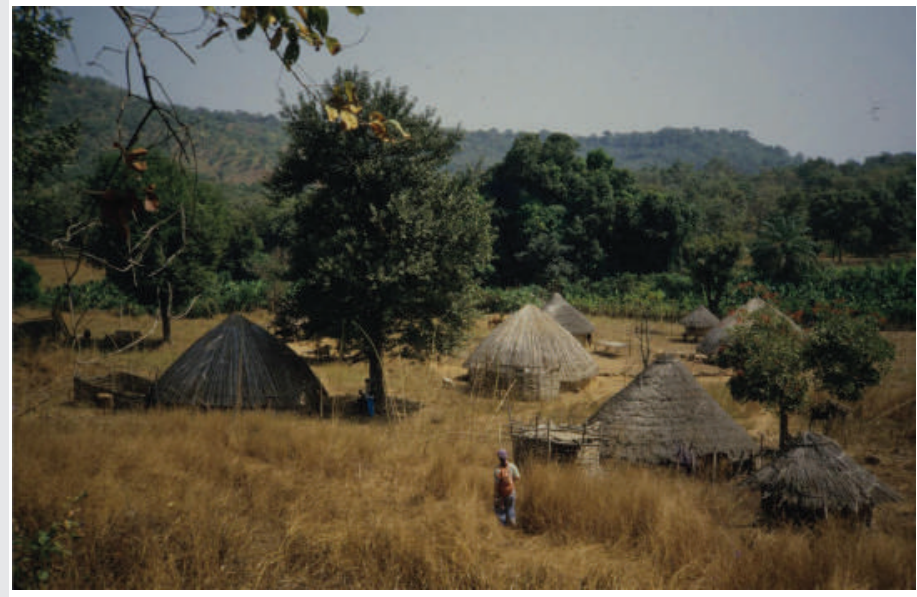

Figure 2: Typical Village, Eastern Senegal/Guinea, 1980s, with ever-expanding human populations encroaching upon wildlife habitat. Source Photo: Author.

its people. To continue blindly along this line of thinking is just as bad as being in the animal rights movement - as in the long-term it will mean the demise of Africa's wildlife and a bleak future for its people.

\section{This is because:}

1) Due to capture of benefits linked to wildlife by the other stakeholders (government, safari and tourism operators), and due to the low resource to population ratio, CBNRM (Community Based Natural Resource Management) benefits tend to be negligible at the level of the household and are mostly used for common property benefits such as roads, schools, clinics, boreholes, etc. $[1,2]$ These benefits on their own are important, but may not stop traditional resource users (e.g., hunters, sawyers, fishers, wild medicine collectors, etc.) from poaching to feed their families unless they are integrated into the management of these areas, and/or from converting natural systems into man-made systems (e.g., for agriculture and livestock). As one resident responded, living alongside Bwindi Impenetrable Forest that had been turned into a gorilla reserve - with benefits promised from eco-tourism, "Your schools, clinics and roads are well and good, but they don't fill empty bellies or pay school fees. We want access to the forest" $[1,3]$ for timber that earned them money from pit sawing, bushmeat, etc. and,

2) 70-90 percent of foreign aid returns to the donor country with very little reaching the poorest of the poor [1]. Foreign aid, if properly used could change the face of Africa, creating a large urban middleclass while conserving Africa's unique mega-fauna and habitat.

The importance of bushmeat, both economically and culturally

While bushmeat is an important source of protein (Figures 3-5), most laws in Africa force Africans to poach (Figure 6). Unmanaged and with an increasing demand by an ever-growing human population stuck in poverty, this is not sustainable.
Along with training youth from rural Africa in wildlife management, there is a crying need to integrate traditional hunters in Africa into the management and sustainable harvest of "THEIR" wildlife!

I can't tell you how many times I have heard game guards and even traditional hunters (poachers) come to the same conclusion - you have one of two choices if you don't want the poachers to poach, kill them or help them find another way of life (Figure 7) - which could be integrating them into the management of these natural areas so they don't have to poach and/or educating they and their children so they are able to pursue alternative livelihoods.

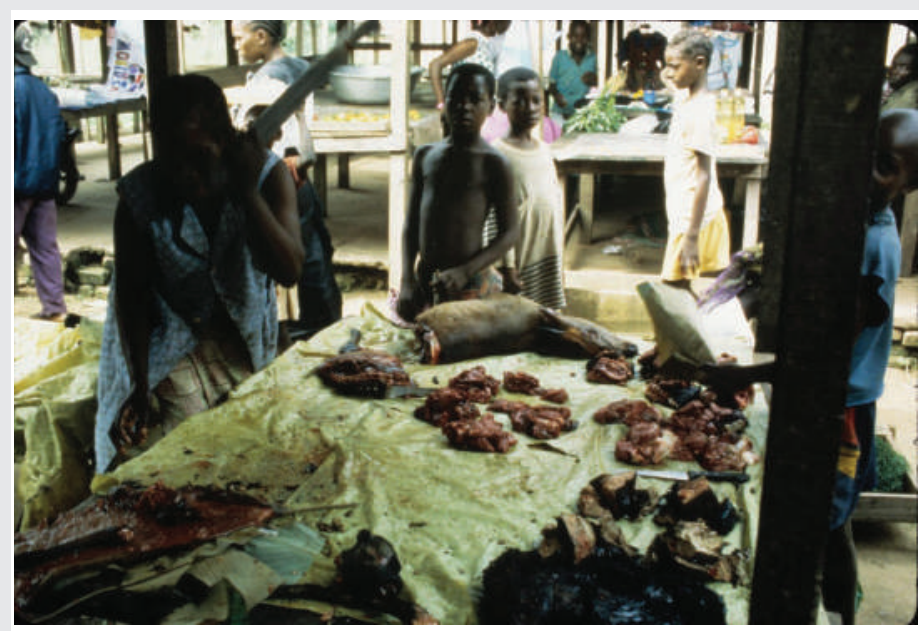

Figure 3: Bushmeat, a major source of protein for much of Sub-Saharan Africa, in Ouesso Market, Congo-Brazzaville, 1995. Source Photo: Author.

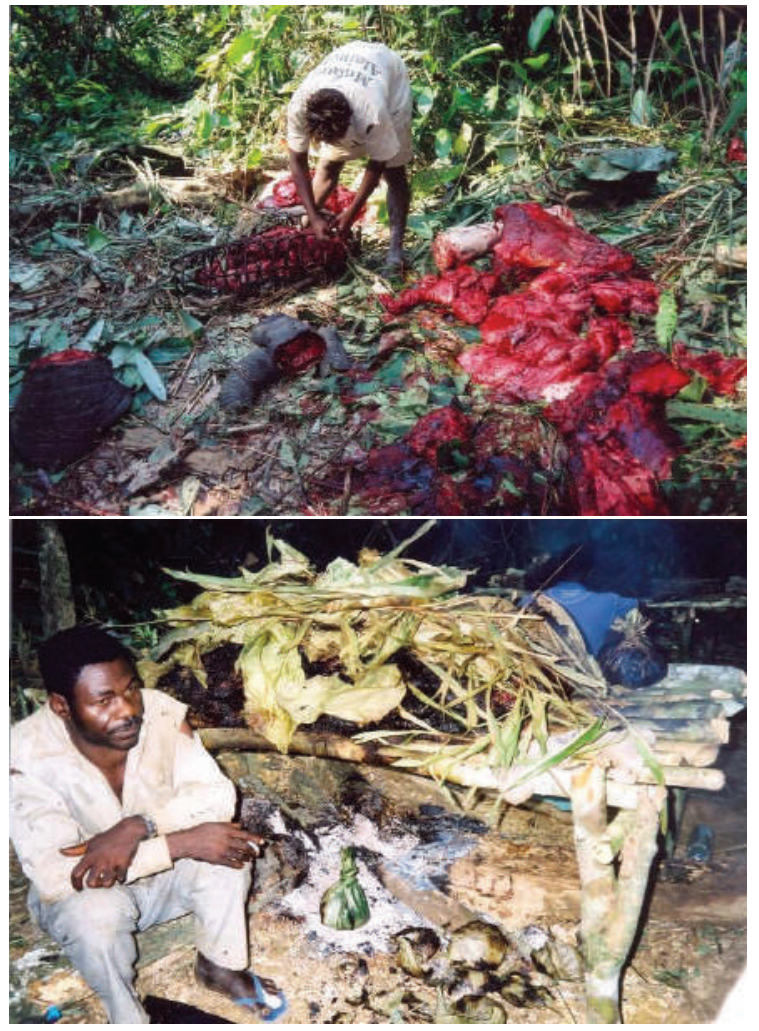

Figures 4,5: Butchered Elephant, Southeastern Cameroon [1]. Elephant meat smoking over fire, Southeastern Cameroon. Source Photos: Author. 
Traditional Hunting - considered poaching by African governments - is about survival, and at the same time, for many a cultural tradition they don't want to give up (Figures $8-11)$ !

\section{To save africa's wildlife we must Save Its People}

We can all agree that to Save Africa's Wildlife we must first Save Africa's People. With a human population that will more than double in the next 50 years, unless there are major changes, the 2000 Sub-Saharan African population at about 622 million is projected to more than double by 2050 (Figures 12,13). If the majority of the people are stuck in subsistence lifestyles and/or in urban slums rotating back and forth between urban and rural areas poaching wildlife, timber (Figures 14-16), fish, etc. and converting natural systems into man-made systems for farming (Figure 17) and livestock, what Zimbabwean professional hunter ( $\mathrm{PH})$ Andy Wilkinson coined "Politics of Despair" - then the people and the wildlife are doomed $[1,2]$.

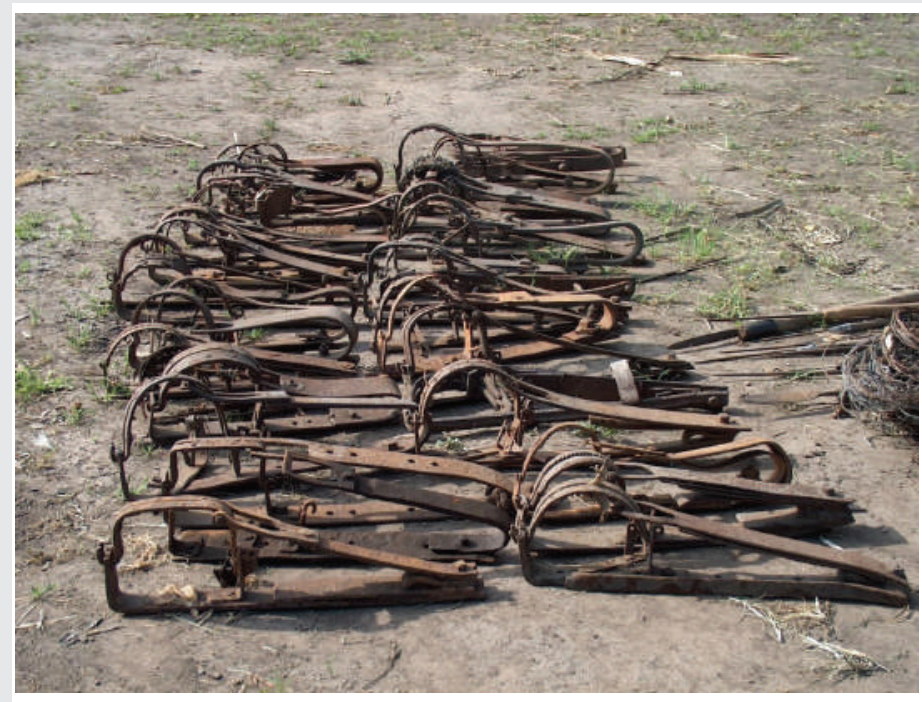

Figure 6: Snares and gin traps recovered in hunting block Coutado 14, Merromeu Game Reserve, Mozambique, 2000s. Source Photo: With permission, Toni Wicker, Nyati Safaris.

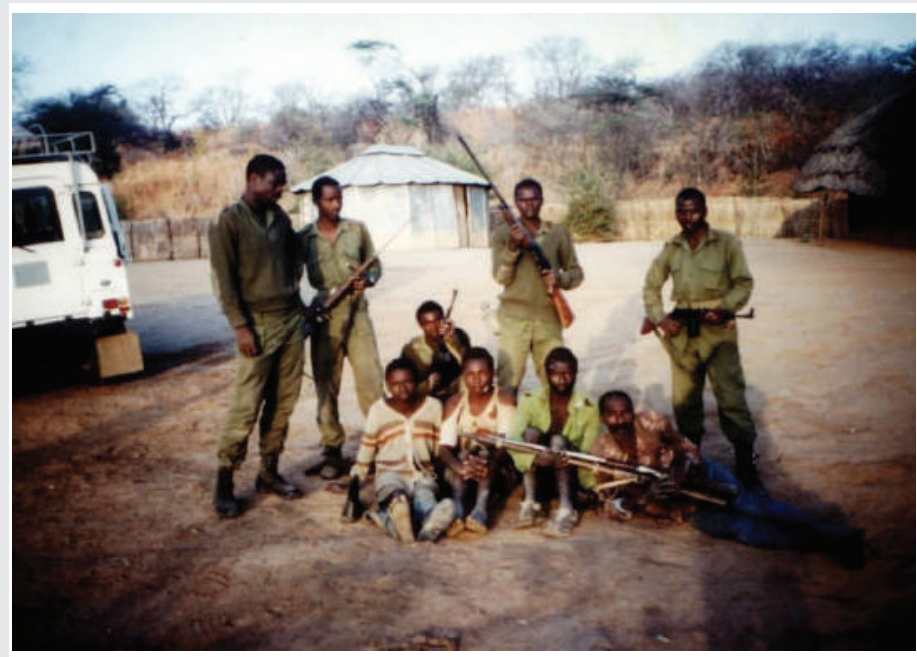

Figure 7: Elephant "poachers" captured by game guards, Munyamadzi Corridor, Zambia, early 1990s. Game guards said, "we have one of two choices, either shoot them or help them find viable long-term employment" [1,4]! Source Photo: Author.

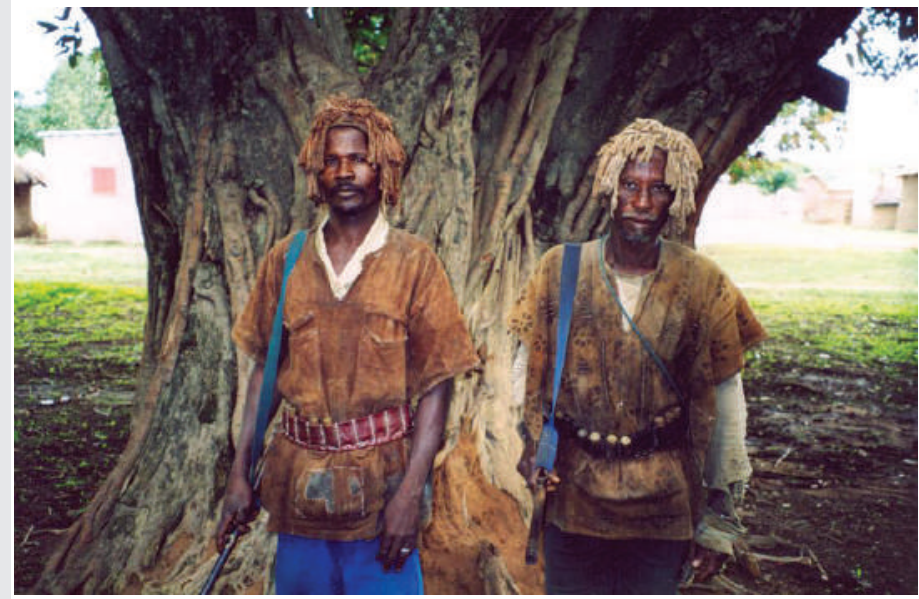

Figure 8: Dozo Hunter/Warriors, Comoé-Léraba Reserve is located in the southwestern part of Burkina Faso, on the border with the Ivory Coast. Source Photo [1]
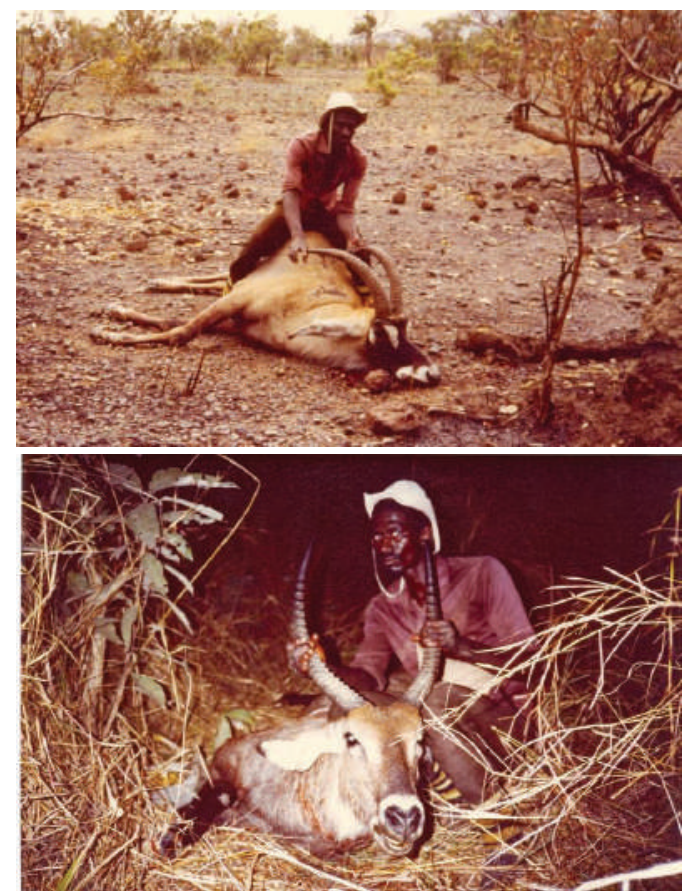

Figures 9,10: Roan/Antelope Cheval (Hippotragus equinus) \& Sing-Sing Waterbuck/ Cobe Defassa (Kobus defassa) with "Great Black Hunter" Wali Samurhaï, Mandinka/ Malinké ethnie, Mahina Mine, 1985, Zone d'Intérêt Cynégétique de la Falémé, Senegal along the Mali and Guinean borders. Source Photos: Author.

\section{Failure of foreign aid}

Let's be honest - conservation on its own has a very important role to play in contributing to development, but on its own will fail to save wildlife or help the people escape poverty $[1,2]$. Why aren't more people, who are concerned

${ }^{3}$ The origin of the Donso (Dozo) hunting guilds date back to the 1236 A.D. under the Mali Empire of Sundiata Keita. They consider themselves professional. Their hunting garb consists of an earthy dyed tunic and a special hat that looks like a wig. Gris gris are special amulets prepared by Moslem marabous and worn by the Dozo to protect them from evil spirits. The apprentice hunter "donso dewn" and his hunting over a 3-6-year period is controlled by the "master hunter" or "donsofa, donso-koutigui or kalanfa". He is steeped in the traditions of hunting, transformation into lion and other creatures, traditional medicine and protection against the genies of the bush [1].

Citation: DeGeorges PA (2020) Why Reforming foreign Aid is Critical to the Future of Africa, Africans \& Their Wildlife. Glob J Ecol 5(1): 099-114. 
about the future of Africa, its people and "THEIR" wildlife, crying out about how Foreign $\mathrm{Aid}^{4}$ has been used - failing to lift a significant portion of people out of poverty, failing to turn wildlife into an economic resource that can keep up with human population growth and their economic demands - but creating dependency and exploiting Africa's vast natural resources with minimal benefits to Africa and Africans, and creating more areas of protection than of conservation/sustainable use. Our book $^{5}$ [1] goes into these issues in great detail.

This brings me back to conservationists (us hunters and fishermen, ecologists, wildlife managers, safari operators, etc.). There is a need for the African conservation community to meet with the U.S. Fish and Wildlife Service to discuss how many of their policies detrimentally impact Africa's wildlife, conservation and development programs (e.g., stopping

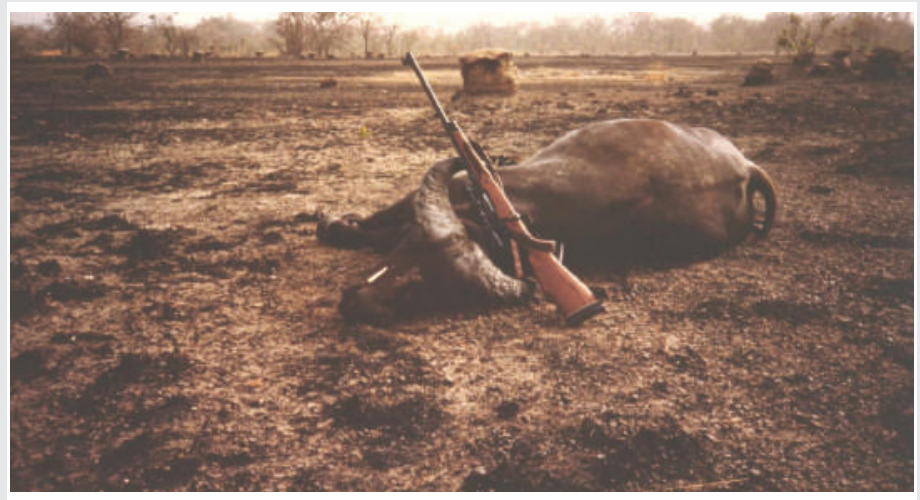

Figure 11: Typical West African Savanna Buffalo (Syncerus caffer brachyceros) taken with traditional hunter Wali Samurhaï, 1980s. Source Photo: Author

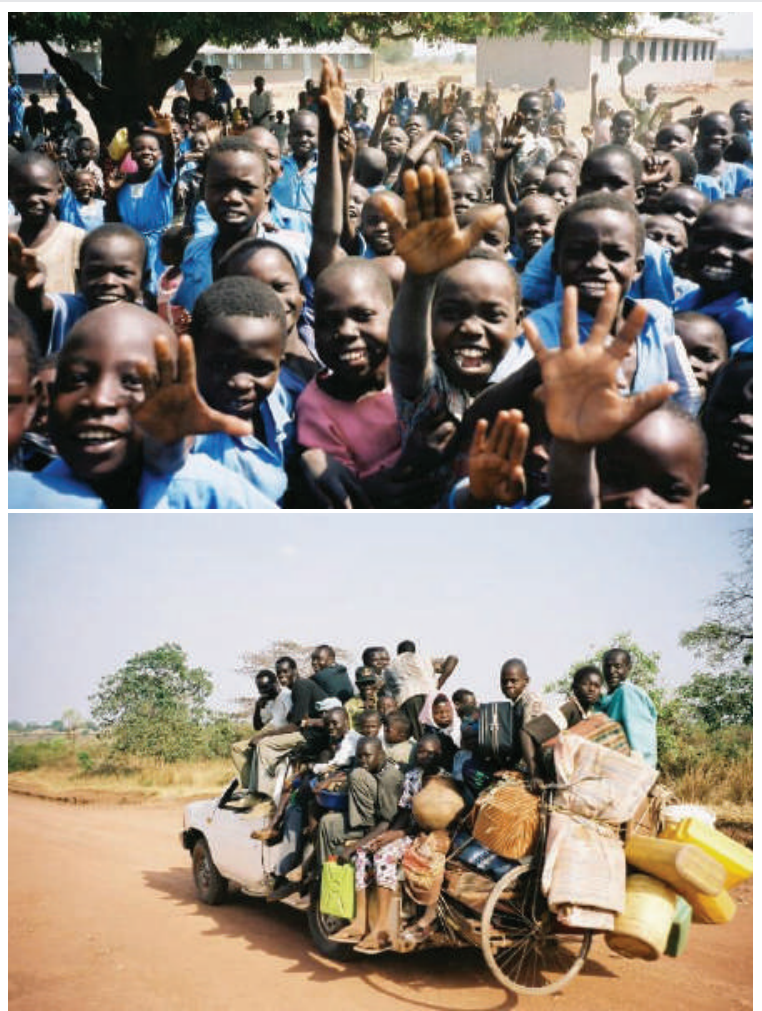

Figures 12,13: The biggest threat to Wildlife in Sub-Saharan Africa is habitat loss from a human population stuck in subsistence lifestyles that will more than double in the next 50 years, Uganda, 1990. Source Photos: Author.

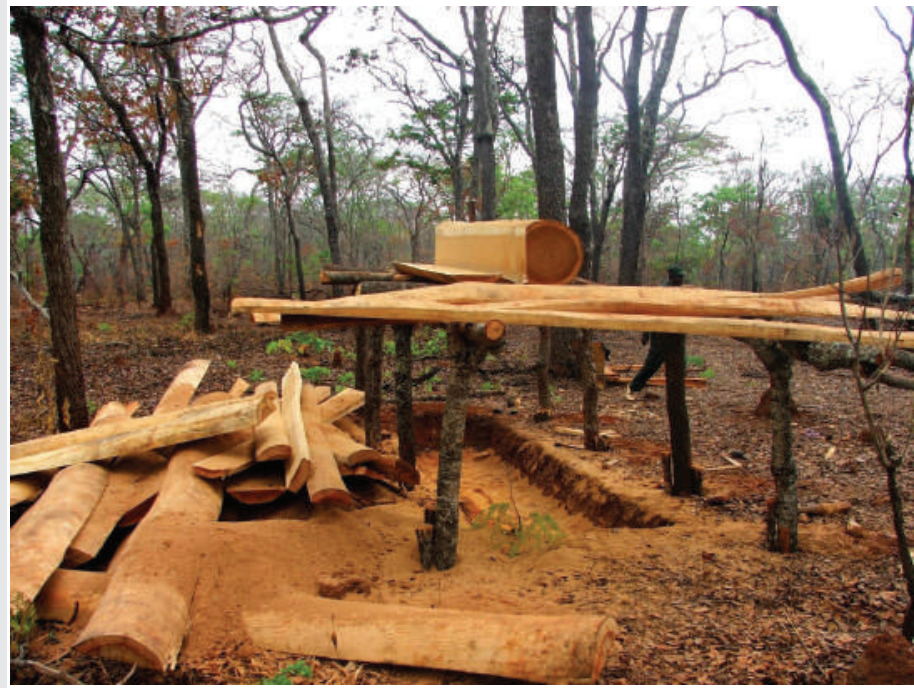

Figure 14: Unmanaged pit sawing, along with charcoal making, contributing to deforestation across. Sub-Saharan Africa. Source Photo: With permission, Badenhurst, Andre, Tanzania, 2000s.

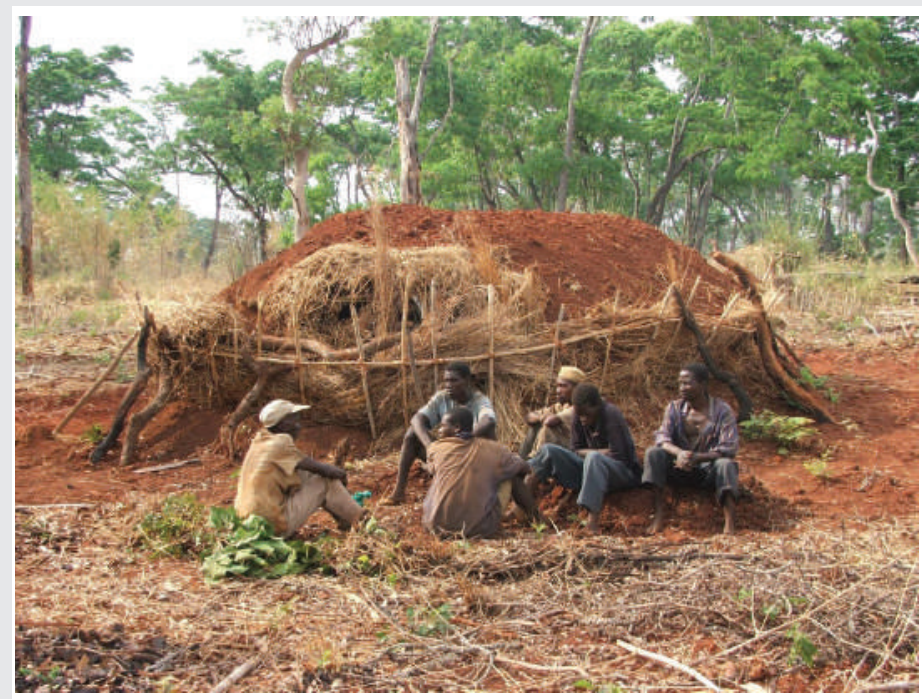

Figure 15: Unmanaged Charcoal Production. Source Photo: With permission Badenhurst, Andre, Tanzania, 2000s.

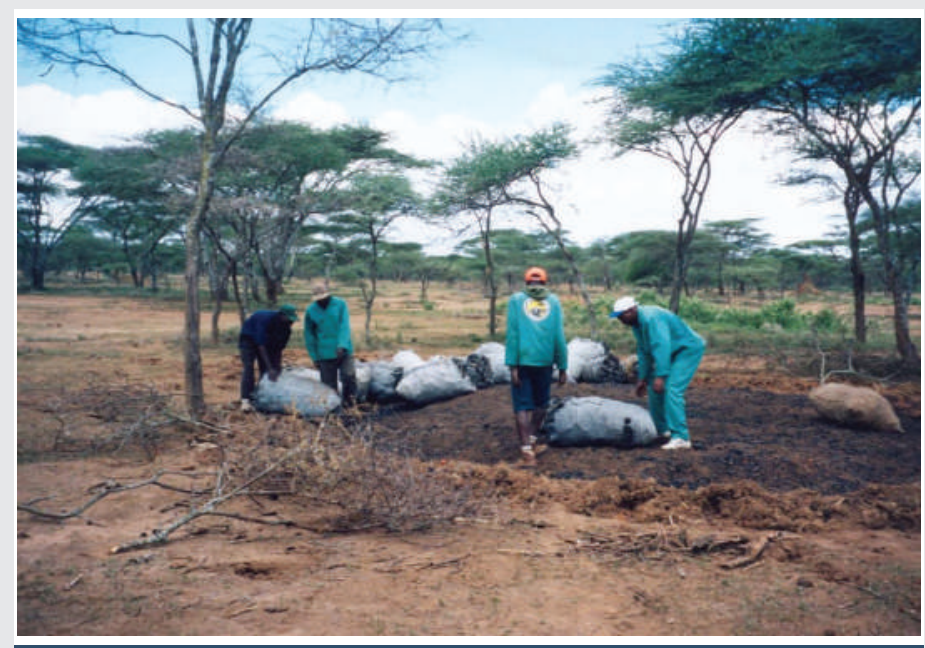

Figure 16: Unmanaged Pit sawing and charcoal making that could be sustainably managed, along with decreasing agricultural fallow periods, are resulting in the deforestation and significant loss of wildlife habitat in Sub-Saharan Africa, Tanzania 2000s. Source Photo: Author.

Citation: DeGeorges PA (2020) Why Reforming foreign Aid is Critical to the Future of Africa, Africans \& Their Wildlife. Glob J Ecol 5(1): 099-114. 
${ }^{4}$ Overseas Development Assistance (ODA), flow of official financing to the developing world that is concessional in character, namely grants and loans with at least a 25 percent grant component, most often referred to as "foreign aid", the loan component contributing to the buildup of both bi-lateral and multi-lateral debt [1]

${ }^{5}$ DeGeorges, P.A. \& Reilly, B.K. 2008. A critical evaluation of conservation and development in Sub-Saharan Africa: Last Chance Africa. The Edwin Mellen Press, Lewiston, New York. 7 books, 3,572p. Downloadable for free on ResearchGate under my name, Andre DeGeorges.

imports of hunting trophies from Africa that generate revenue for Community Based Natural Resource Management (CBNRM) programs, as well as for anti-poaching activities), but also with USAID (U.S. Agency for International Development) to discuss how Foreign Aid is used in the name of conservation and development in Sub-Saharan Africa, but in many cases encourages more protectionism (e.g., parks and wildlife reserves) - kicking the people off "THEIR" land and cutting them off from accessing "THEIR NATURAL RESOURCES" upon which they survive, while trying to solve all the problems on the farm - "Failed" Integrated Rural Development. This often compresses them into areas that can no longer sustain their livelihoods. In addition, about $70-75 \%$ of Sub-Saharan Africa is comprised of savannah biome. Its best land use is as pasture for wildlife and livestock, but while marginal, is increasingly being used by itinerant farmers in search of new lands as fallow periods disappear across the subcontinent due to soaring human populations. This is resulting in severe environmental degradation and a zone of conflict between pastoralists and farmers across the sub-continent, and often between park managers, farmers and herders [1]. As human and livestock populations increase, along with poaching, encroachment into parks, game reserves and hunting blocks by herders and farmers is being seen across Sub-Saharan Africa, competing with wildlife and its habitat [Figures 18-20], [1].

And then as a means of influencing "conservation" policies that often end up being more protectionist than conservation/ sustainable use, there are the donor funded trips for the

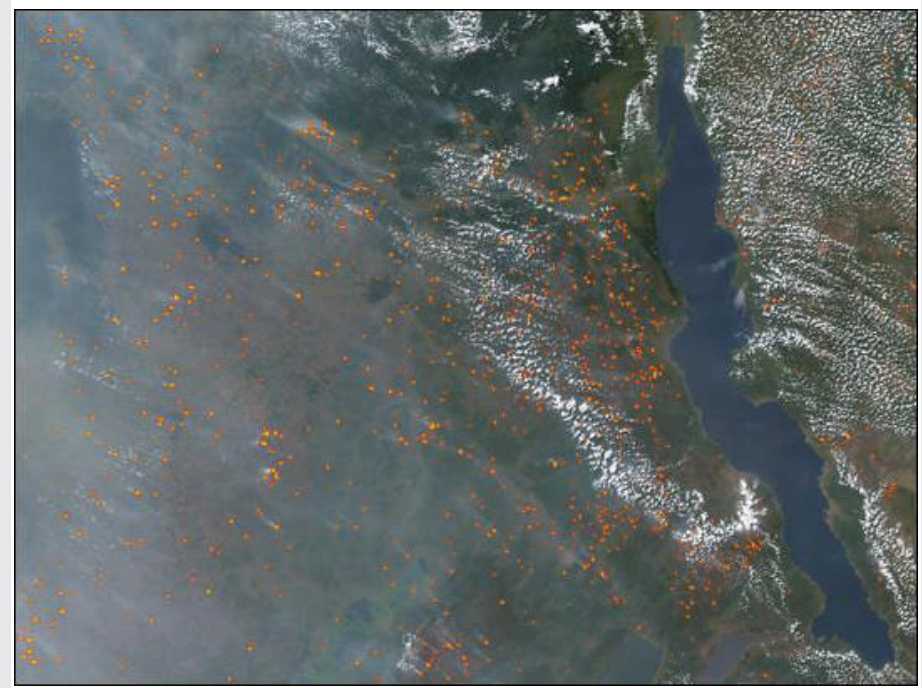

Figure 17: Fires from slash and burn agriculture west of Lake Tanganyika in EastCentral Africa. May 23, 2004 as forests are turned into agricultural plots by an evergrowing population stuck in poverty \& subsistence. Source: NASA (2004), U.S. Government public domain [1].

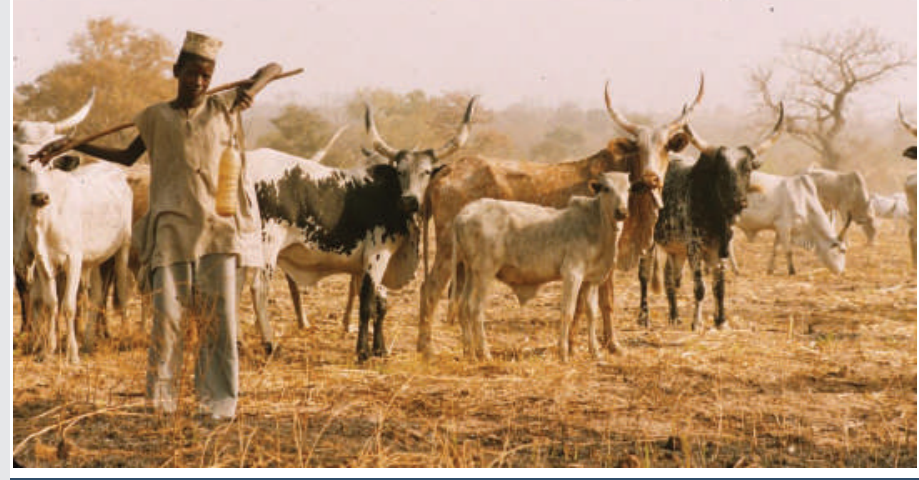

Figure 18: Fulani Herder inside Bénoué National Park, Northern Cameroon, 1990s. Not uncommon across Sub-Saharan Africa. Many of these parks once served as critical dry season grazing areas for both wildlife and livestock. As human populations increase and pasture is converted to farmland, there are increasing herder/farmer conflicts, as well as increased uncontrolled grazing in national parks. Source: Author

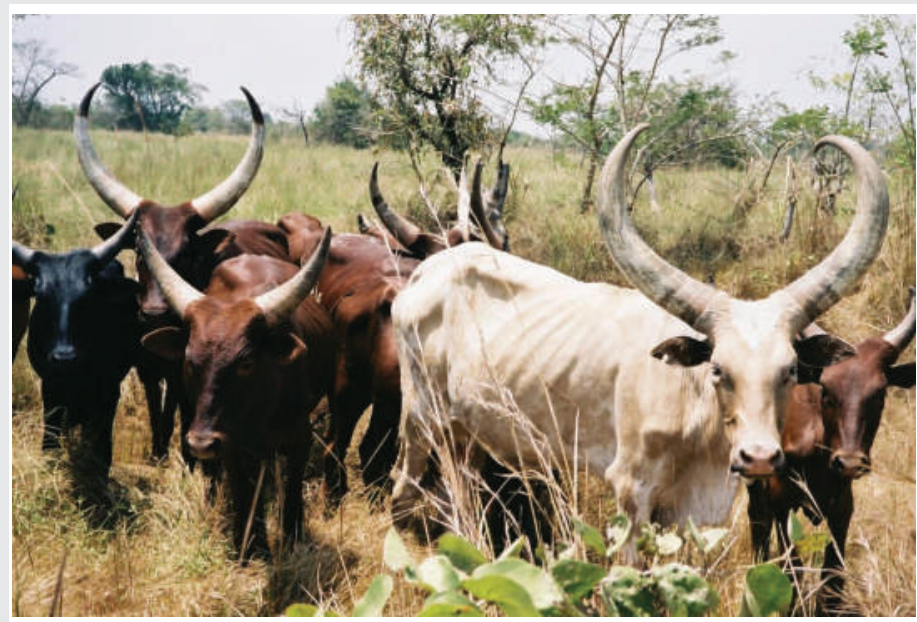

Figure 19: Ankole Cattle, Uganda 2002. As human populations increase so do their livestock, which displace wildlife, often a sign of wealth, as well as food. Source Photo: Author.

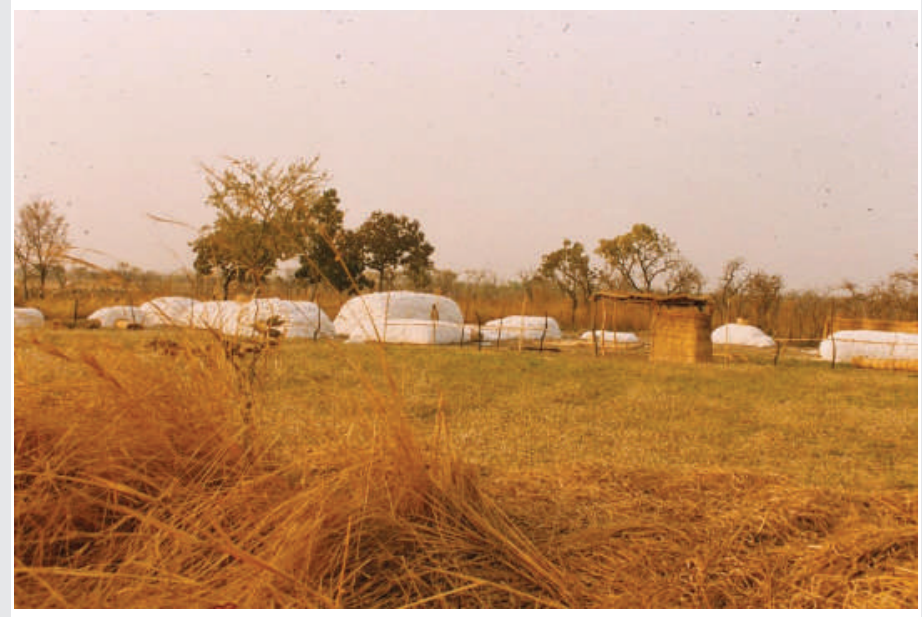

Figure 20: Cotton farmers encroaching upon hunting blocks, Northern Cameroon, 1990s. Source Photo: Author.

bureaucratic and political elite with per diems that sadly are often higher than their salaries. 
In addition, Western NGOs, coming to Africa, tend to be filled with researchers, not resource managers. These researchers take the Precautionary Principle ${ }^{6}$, as opposed to Adaptive Management ${ }^{7}$ that people like Graham Child \& Ron Thomson pioneered in Zimbabwe. As noted, the actions of these NGOs are often destructive tending to alienate Africans by cutting them off from using and living off their natural resources - while attempting to solve all the problems on the farm like tree farming as opposed to natural forest management aforementioned "Failed" Integrated Rural Development [1,2].

The author has a lot of respect for researchers. They fed him important information that enabled him to put together the above-referenced book. But researchers aren't wildlife/ habitat managers. The author remembers, Dr. George Hughes Chief Executive Officer (CEO) of the Natal Parks Board that evolved into the KwaZulu Natal Nature Conservation Service and today's Ezemvelo KZN Wildlife, South Africa - telling him that his reserves/parks were run by managers using the described Adaptive Management approach to wildlife and habitat, while researchers focused on filling very narrow data gaps that fed into the decision-making process of the reserve manager.

University trained Kruger National Park game warden Richard Sowry has warned that most parks in Africa do not generate enough income from ecotourism to support their management, let alone award benefits to peripheral communities [5]. As Ron Thomson ${ }^{8}$ [6] has often recommended, these natural areas, with management and landuse plans, need to be sustainably managed as Green Factories Without Walls for a multitude of resources (e.g., wildlife, fish, timber, charcoal, wild medicines, honey, etc.) - something that Africans with proper training and management experience could pull off with the rural communities, but which $99.9 \%$ of the Western NGOs filled with researchers and urban yuppies, are not qualified to undertake. This would mean that the majority of protected areas in Africa need to be reclassified from exclusion zones of IUCN (International Union for Conservation of Nature)

\footnotetext{
${ }^{6}$ Precautionary Principle - The protectionist approach, founded in Western urban industrialized settings where humans have lost their dependency on surviving directly off the environment, purports that wildlife and its complex life cycle must be fully understood before it can be used and that this requires time and extensive research This results in passive management of the species, allowing "natural regulation" to dominate as the management approach, which assumes that nature will take care of itself [1]

${ }^{7}$ The Adaptive Management approach relies on a crude evaluation of wildlife resources based on available data on a specific species in order to make conservative estimates of sustainable off-take. This off-take is monitored while data gaps are identified and filled to help make better management decisions on how to best utilize wildlife as an economic and rural development tool for rural Africa: Preliminary but conservative quotas based on field surveys; Adjusting quotas annually based on an appropriate and cost effective wildlife monitoring program [e.g., trophy quality, hunting success, hunting effort, herd structure and size, recruitment, aerial surveys (if available), along with decision support, rainfall, pasture quality]; and based on a theoretical off-take of only 2-5\% of annual game population for trophies and another $10-25 \%$ for meat. Adaptive Management is the basic tenet of Southern Africa's ap proach to sustainable use. It is a pre-requisite for CBNRM to begin, since poverty, despair, alienation and disenfranchisement will not wait for Western scientists to study wildlife and its habitat to extinction and to the detriment of the people and their resources [1].
}

Categories I-V to IUCN Category VI - Managed Resource Protected Area: protected areas managed BY AFRICANS mainly for the sustainable use of THEIR natural ecosystems. "An area containing predominantly unmodified natural systems, managed to ensure long-term protection and maintenance of biological diversity, while providing at the same time a sustainable flow of natural products and services to meet community needs" [1].

\section{Hunting as a conservation \& development tool in Sub- Saharan Africa}

Michel Mantheakis, Chairman of the Tanzania Hunting Operators Association (TAHOA), asks - how is it that hunting helped recover wildlife in America, but can't be used in Africa [7] [Figure 21]?

In East \& Southern Africa where a combination of Community Based Natural Resource Management (CBNRM) in communal areas and private game ranching exist, wildlife and its habitat are secure and thriving, while bushmeat is common on everyone's dinner table [Figure 22]. The rest of Africa is struggling to maintain both wildlife and related natural systems $[1,2]$.

\section{Failed kenya preservation model}

Closing hunting, given the current socio-economic situation in Africa today, means "The End of the Game" as

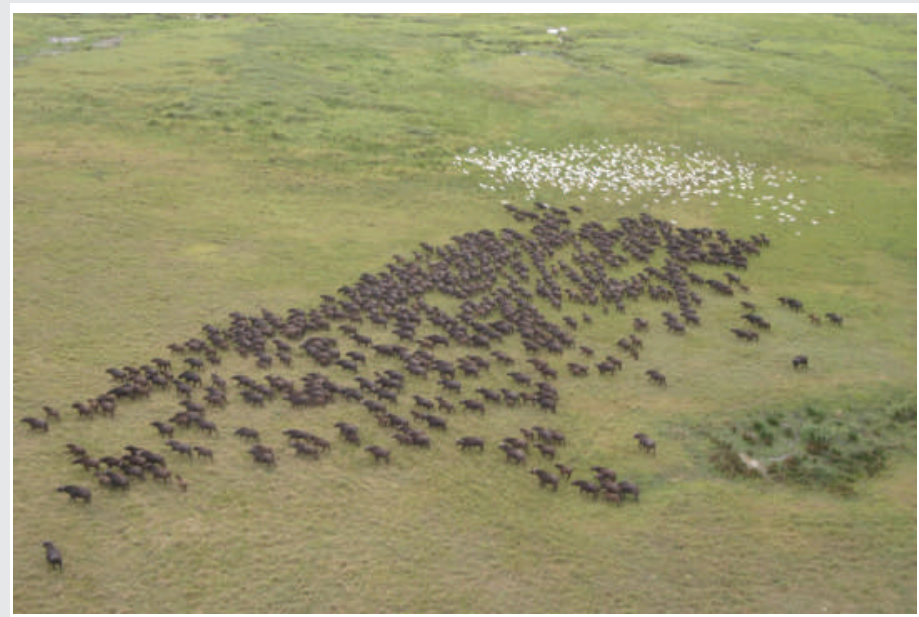

Figure 21: Safari Operators, sharing benefits, employing and involving rural communities in conservation, through CBNRM (Community Based Natural Resource Management) contribute to the conservation of the most diverse mega-fauna in the World - that of Sub-Saharan Africa. Cape Buffalo (Syncerus caffer caffer) herd in one hunting block Coutado 14, Merromeu Game Reserve, Mozambique, 2000s. Source Photo: With permission Toni Wicker, Nyati Safaris.
${ }^{8}$ Former employee of Rhodesian Department of National Parks and Wildlife Management. including Provincial Game Warden-in-charge Hwange National Park. Served as Chief Nature Conservation Officer, Ciskei; and Director of the Bophuthatswana National Parks Board, South Africa. He operated as a Professional Hunter for three years; and for the last 27 years he has been a full-time author. He is a universitytrained Field Ecologist (cum laude); a long-time member of the Institute of Biology (London); and, former Chartered Biologist for the European Union. He is Chief Executive Officer (CEO) of the NGO True Green Alliance, has written many books on conservation and wildlife management, and oversees the website https://www.mahohboh org/the-team/ 


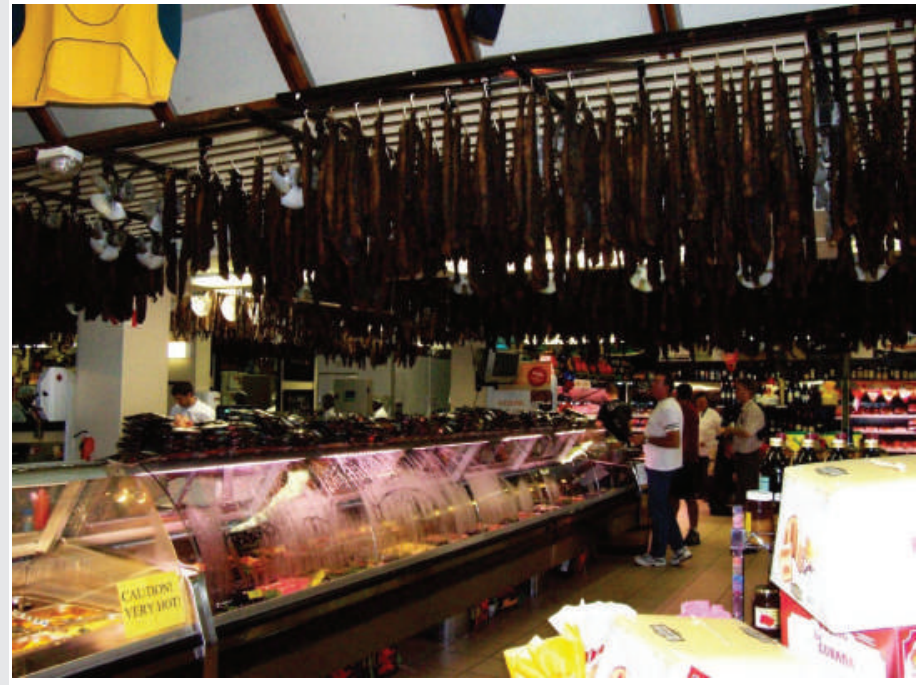

Figure 22: Typical South African Butchery circa 2007, with Game \& Beef Biltong/ Jerky hanging from the ceiling. South Africa has the largest sustainable commercial bushmeat trade in the World \& with properly trained people and appropriate policies, bushmeat can be sustainably managed as an economic, nutritional and cultural resource throughout Sub-Saharan Africa. Source Photo: Author.

per Peter Beard [8]. Just look at Kenya's wildlife today that closed hunting in collaboration with Western Donors and their Animal Rights NGOs and whose game populations have been devastated by rural people [Figure 23] who own their land but not their wildlife, receiving little economic benefits from this natural resource:

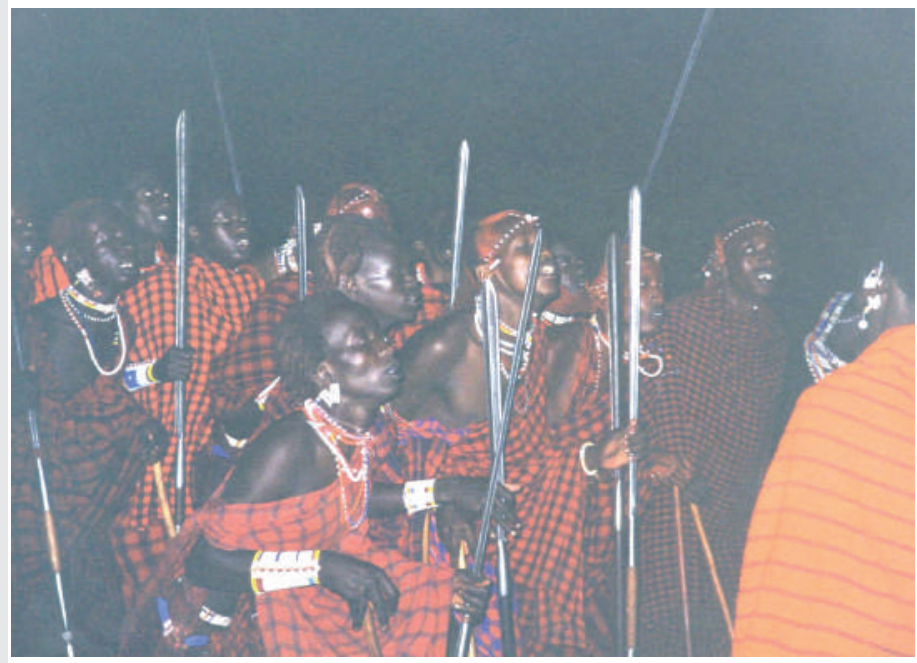

Figure 23: Proud Maasai Moran/Warriors during ritual, famous for group lion hunting with spears, Tanzania \& Kenya, 1990s. Maasai pastoralists traditionally cohabited with wildlife throughout Kenya and Tanzania. Source Photo: Author.

"Privately-owned Laikipia ranches, many owned by independently wealthy, often expatriate, landowners, continue to serve as strongholds for wildlife, including elephant and rhino populations. Laikipia is the only district where wildlife recorded an increase in numbers, up 12\% between 1977 and 1994, with many of the other range lands seeing wildlife decreases ranging from negative $40-80 \%$, and even important areas such as Amboseli/Kajiado District with a decrease of negative $15 \%$ and Maasai Mara/Narok District wildlife populations down by negative $32 \%$...As the well-known safari operator Robin Hurt, who was raised in Kenya explained, "When I was a boy there were 'Islands of People' surrounded by a sea of wildlife. Today, there are 'Islands of Wildlife' surrounded by a 'Sea of People'". Both he and Fred Duckworth estimate that wildlife in Kenya and Tanzania is $25 \%$ of what it was in their youth; a $75 \%$ reduction in numbers. These men are in their 60s" [1].

It is estimated that between $65 \%$ and $80 \%$ of Kenya's wildlife is found outside National Parks and Reserves. The areas outside the parks/reserves serve as rainy season dispersal areas where young are born, as well as giving habitat within these protected areas an opportunity to recover from grazing/ browsing; also true for Tanzania. Due to the antiquated preservationist policies of Kenya Wildlife Service (KWS) (e.g., closure of safari hunting in 1977), wildlife on private (Laikipia ranches being an exception), group and cooperative ranches has been, and is still seen as an Open Access Resource competing with livestock and of no long-term economic value to 99 percent of Kenya's residents. One of the worst governmental and Western donor (e.g., World Bank) policies ever introduced was the creation of group ranches in Kenya, without regard for ecological complementarity (a ranch needing wet and dry season habitat for extensive management). In many cases these group ranches being too small to support traditional nomadism, were subdivided and sold to small farmers. Also, many parks depend on Maasai lands as rainy season dispersal areas for wildlife, necessary to maintain quality habitat within the parks. While individuals and/or groups have title deeds to the land, they lack ownership over the land's most valuable commodity, wildlife. The drastic decline of wildlife and wildlife habitat can be attributed to the pathetic protectionist policies of the (KWS), giving no incentive to ever-increasing rural people to maintain these communal ranches in natural systems. Overall, in Kenya, it is estimated that large herbivores in the rangelands have declined by $60-70$ percent between 1977 and 2007. The author, as Regional Environmental Advisor to USAID/REDSO/ESA (U.S. Agency for International Development, Regional Economic Development Services Office for East Africa in East and Southern Africa) 1990-1992, will never forget a meeting in USAID when he raised the idea of hunting as a conservation and development tool - Jorie Butler Kent of Abercrombie and Kent (ecotourism company) jumped up and yelled at him in anger saying that Kenya would never be like Southern Africa. In April 2000, at CITES ${ }^{9}$ COP 11 in Nairobi, the principal author was shocked as he drove along the rift valley escarpment road from Nairobi to Naivasha. Down in the valley, what had been bush, when the author lived in Kenya during the early 1990s, was now a neat quilt of squares, small farms expanding into what had been wildlife/livestock habitat less than ten years before. Movement of small farmers, mainly Kikuyu, into former Maasai grazing areas in Kenya is resulting in major conflicts in the $20 / 21$ centuries, as noted, with similar problems across Sub-Saharan Africa [Figures 24,25]. In high rainfall areas, group ranches, critical rainy season grazing areas to parks such as those surrounding Maasai Mara, are

${ }^{9}$ Convention on International Trade in Endangered Species of Wild Fauna and Flora (CITES), Conference of the Parties (COP). 


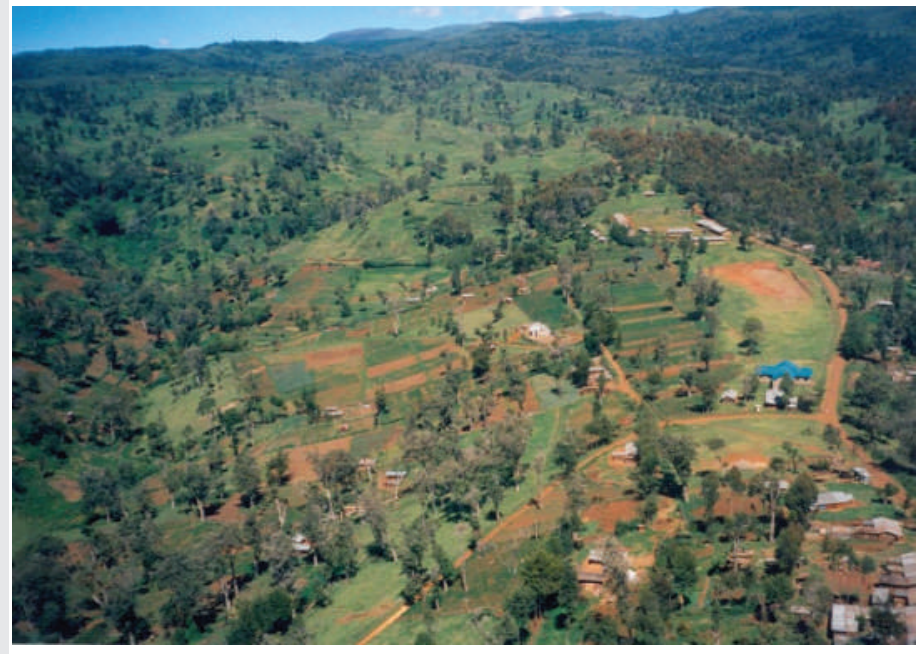

Figure 24: Sub-divided Kikuyu Highlands late 1990s, Kenya with little room for expansion except into marginal areas putting them into conflict with traditional pastoralists in the 20th and 21st centuries. Source Photo: [1].

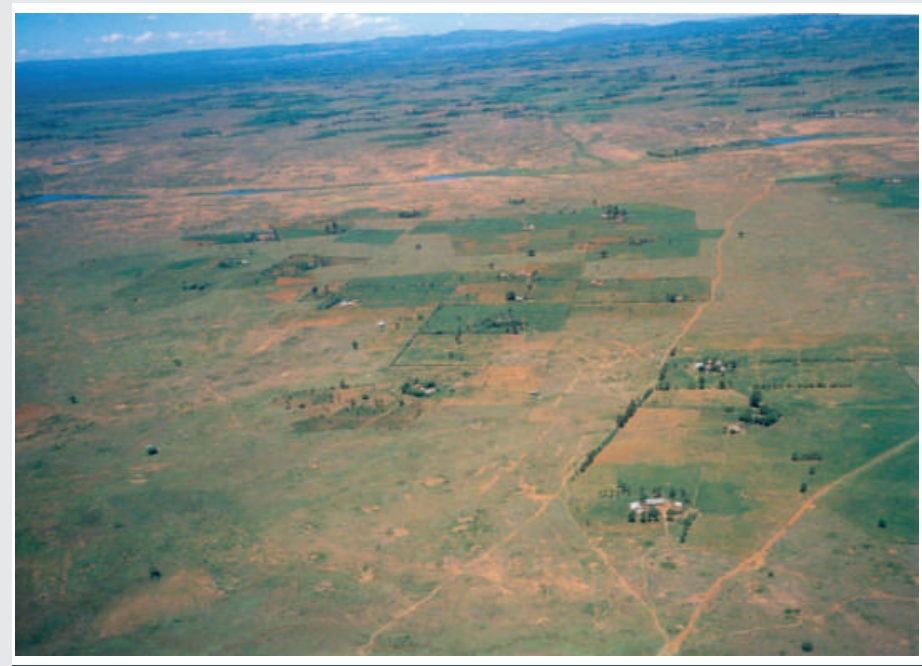

Figure 25: Movement of small-scale farmers, mainly Kikuyu into former Maasai grazing areas in Kenya, resulting in major conflicts in the 20/21st centuries, 2000, Rift Valley taken from Nairobi/Naivasha Road. Source Photo: [1].

being sold off to commercial wheat and maize farms. All of this is the consequence of Western donors teamed up with the animal rights movement to impose poorly thought out land use policies, combined with the concept that eco-tourism (preservation) would save both the wildlife and the people, with the consequences seen in these photos and wildlife surveys [1].

Due to the antiquated laws of the Kenya Wildlife Service (KWS) that favor Livestock over Wildlife, in the 1980s, White ranchers Clive (pers. comm.) and George Aggate of Kifluku Farm, Laikipia Kenya, built a stone wall around their 3,644 ha (9,000 acre) farm and shot out all wildlife [Figure 26]. They then approached the Kenya Wildlife Service and explained that they had the right to control problem animals and since wildlife had no direct value to them, they were all problem animals bringing in tick borne diseases, and competing with livestock for pasture. Until they could obtain reasonable value from wildlife, they didn't want wildlife on their land, being no different than any smallholder. Clive challenged the Kenya Wildlife Service (KWS) to take him to court. They refused,

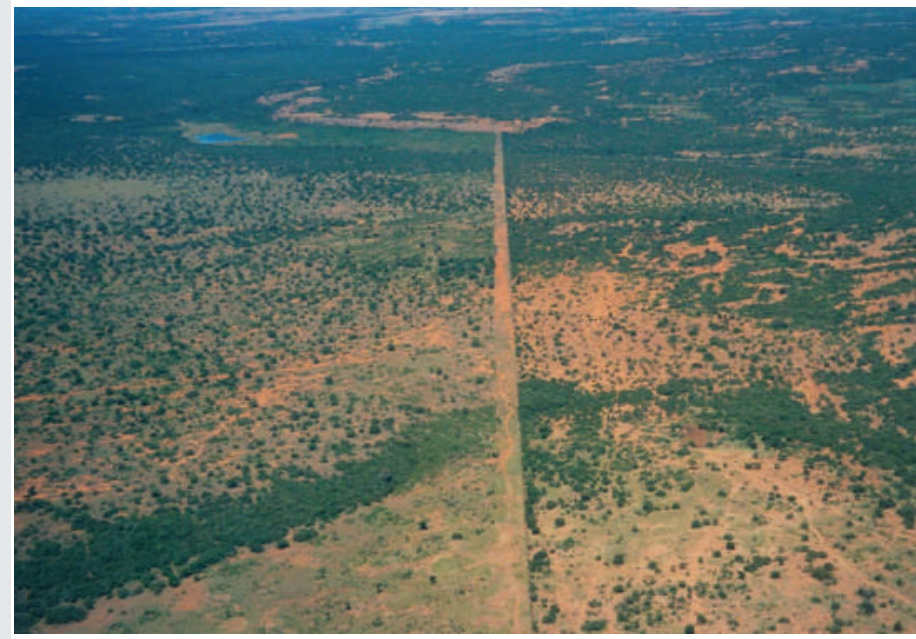

Figure 26: Wall built along border of Kifluku Farm, Laikipia Kenya to keep wildlife from interfering with livestock, as wildlife had no value to White ranchers Clive \& George Aggate. Source Photo: Author.

fearing that legally he would win the case and set a precedent for other smallholders in Kenya [1].

\section{Next-door tanzania}

In next door Tanzania, wet season populations of the most numerous wildlife in the Tarangire-Manyara ecosystem, wildebeest (Connochaetes taurinus) concentrated largely in the Simanjiro plains east of the park during this period, have declined from a high of 43,539 in 1988 to 5,257 in 2001, while cattle have increased during the same time frame from 53,828 to 240,842 . This latter figure is ten times higher than the most abundant wildlife species in 2001, the zebra at a wet season population of 25,280 (41,073 in 1988). Farm plots increased from 1,051 in the wet season of 1988 to 49,114 during the wet season of 2001 in the Tarangire-Manyara ecosystem, largely in the Simanjiro plains east of Tarangire National Park, impacting the migratory routes of wildlife, especially wildebeest. This is not unique to Maasailand, but is happening across the subcontinent as people opt for other land uses. For instance, in 2004, there were an estimated 1,000 +/ 300 buffalo and $22,500+/-2,500$ cattle in the Moyowosi South hunting block of western Tanzania. The largest herd of buffalo observed was about 400 , whereas 20 years ago herds of up to 6,000 buffalo were commonly observed [ 9 in 1 ].

Also, according to Michel Mantheakis [7], due to influence and infiltration by the animal rights movement, trophy import bans from Tanzania by the U.S. Fish \& Wildlife Service (elephant trophies in 2014 and lion import bans into USA in 2016) have resulted in 81 of the 157 well-managed hunting concessions [Figure 27] being vacant and being ravaged by poaching, totaling more than $100,000 \mathrm{Km}^{2}$. Until 2019, hunting areas comprised $32 \%$ of Tanzania's surface area (bigger surface area than the state of Arizona) while National parks comprised only 7\% of Tanzania's surface area. The Tarangire / Manyara / Ngorongoro / Serengeti / Kilimanjaro national parks receive

\footnotetext{
${ }^{10}$ See https://www.youtube.com/watch?v=bgZhUQWIncw\&feature=youtu.be
} 


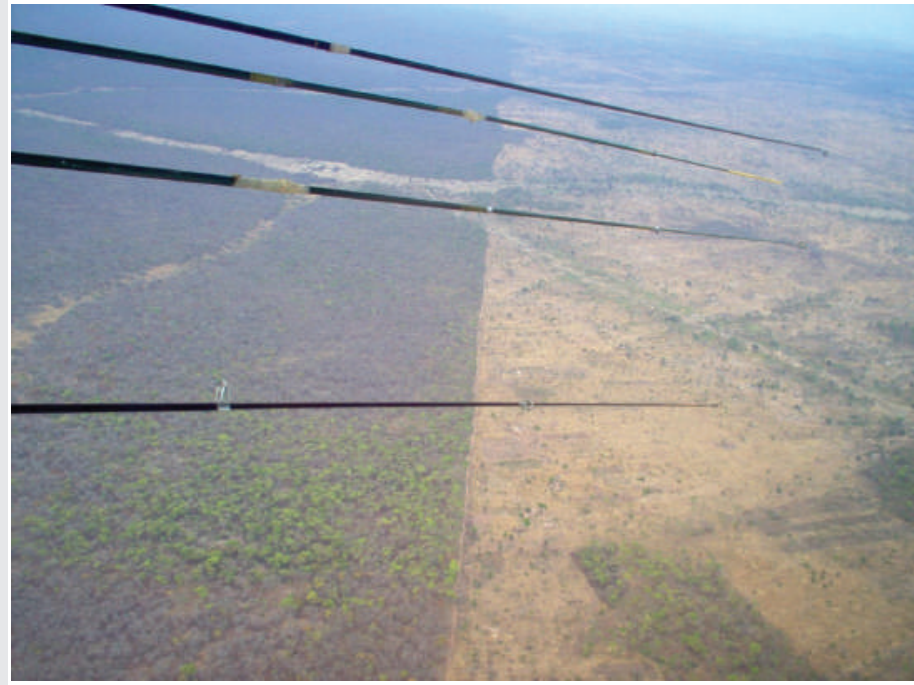

Figure 27: Tanzania, 2004, prior to above-mentioned importation ban of elephant and lion trophies into the United States. Well managed Kigosi Hunting Block, Western Tanzania on left and on right Habitat Degradation from Human Compression combined with Human/Livestock Population increases. Source Photo: Author.

enough tourists to be profitable and subsidize another 14 national parks not viable for tourism. As of 2020, the Tanzania National Parks Authority (TANAPA) has taken over most of the hunting blocks around the Selous Game Reserve, as well as those associated with Burigi, Biharamulo and Kimisi, so national parks now comprise about $14-15 \%$ of Tanzania and hunting blocks, though significant, less than $25 \%$. About $70 \%$ of hunting revenue to Tanzania comes from American hunters. Most hunting areas are not viable for ecotourism lacking the scenery and numbers/diversity of wildlife compared to the top national parks $[7]^{11}$.

\section{Recovery of the eastern whitetail deer in the U.S. a com- parison}

When the author was a boy, the Whitetail deer was down to nothing - back in the 1960s in Maryland, you could take one deer a year, forked horn or larger, no does and if you harvested one everyone came by to see it - I think a lot having to do with the Great Depression and game meat helping people survive. But we hunters collaborated with the fish \& game departments. Thus, what happened is the result of conservation/sustainable use and one can argue Community Based Natural Resource Management. (CBNRM) - we hunters and landowners being the "Community" who collaborated with the government fish and game departments across the U.S. Today, in next-door Virginia there are so many deer, they have become a crop pest, and carry the tick borne Lyme Disease (the author had to take a 10-day treatment about 2-years ago and is now very careful, wearing high rubber boots with my pants tucked in, even when in his yard - it's that bad - but then he abuts up against a farm and it's a 5 minute walk to his deer stand). There are so many deer that the quota is 6 deer a year -3 antlerless and 3 either sex, and then one can buy bonus tags. The author has averaged 5-deer/year between 2009-2019 from a combination of archery, muzzleloader and firearm. He feeds a lot of people. Like many Africans, he lives on deer, catfish/fish and clams on the Eastern Shore of Virginia - buying no meat or fish in the supermarket.

The Eastern Shore of Virginia is a rural area - mainly chicken farms, soybeans, corn, potatoes and watermen (crabs, oysters, clams \& fish). The small farmer is almost a thing of the past - mainly a few big farmers as will likely occur in Africa assuming it can be helped to evolve from a dominant rural based economy to an urban based economy with a large middleclass. Besides, in this global world most youth are more interested in technology jobs than working the soil. The author remembers at Tshwane University of Technology's (TUT) Department of Nature Conservation, how students from all over rural Africa quickly jumped onto computers, iPads, etc.

Many people on the Eastern Shore depend on hunting deer, ducks, dove, rabbit, etc. - as in Africa for both cultural reasons, and for bushmeat - as a major source of protein. If an attempt was made to pull a stunt like in Africa and stop the people from hunting (how foolish these Western NGOs and African Governments are) - poaching would be out of control for both cultural and nutritional reasons - but we hunters and fishers fund the game departments in America with our licenses, so I think we will be left alone. However, one never knows, as society becomes more and more urbanized and people buying their food in the supermarket can't relate to the fact that the saran-wrapped food once had scales, fur or feathers. On the other hand, expressing the same urban views of the animal rights movement trying to stop sustainable use of natural resources in Africa, when the author asks many urban people on the Eastern Shore about eating venison, the response these days is "Oh I can't eat Bambi". If asked, have they ever been to a slaughter house and seen the animals calling out, knowing they are about to die - they shriek and say no! What would you rather be a free-roaming deer/antelope/buffalo/elephant/ etc. and suddenly you catch a bullet, or some domestic animal, living in crowded conditions, wallowing in your manure, herded onto a cramped truck on the way to the slaughter house, and then standing in a line hearing others cry out, knowing you are going to have your throat slit or catch a bullet/plug to the brain? The author would rather be a free ranging deer/game animal.

Yes, it is understood in Africa, at this point in time most people can't afford expensive licenses - but they can be integrated, like in America and Europe, into the management of the game and then there would be few poachers.

Do you realize how many millions and millions of dollars are given to Western NGOs by the foreign aid donors to run conservation programs in Sub-Saharan Africa and "Where is the Beef" maybe better said, "Where is the Nyama" ${ }^{12 " ~-~ I ~ d o n ' t ~}$ see too many dramatic results - except for lots of poaching and habitat loss. Yes, in Southern Africa there is some success with CBNRM, but not enough to lift the majority of people out of poverty $[1,2]$. 


\section{The way forward, education, education, education}

The author's Mother, who grew up on a peach farm in the Appalachian Mountains with 11 brothers and sisters, used to tell him, "What changed America was rural electrification \& the GI Bill" that sent soldier boys after WWII off to university - before that only a small percentage of the population went to university.

Small farmers struggled just like in Africa - one of the author's uncles able to farm full time, one working in a factory at night and farming during the day, another uncle delivering mail and then farming. The rest of her brothers and sisters went off to university and/or found work in urban settings. Today with about 30 cousins, only 1 farms - the rest being doctors, lawyers, salesmen, ecologists, teachers, bureaucrats, businessmen, etc. If in America, we were all stuck in subsistence lifestyles like Africa is today - the Appalachian Mountains would look like Kikuyuland in northern Kenya (Figure 24) - with little subsistence plots and people rotating back and forth between urban slums and rural areas - poaching and destroying habitat.

There is a crying need to send as many African youths as possible off to university, trade schools, apprenticeships, wildlife colleges, etc. or employ them directly in the safari/ ecotourism sectors to help take the pressure off these rural areas."

There is also a need to begin this environmental education at the primary and secondary school levels. As often attributed to St. Francis Xavier, "Give me the child until he is seven and I'll give you the man". The author's Mother- a primary school teacher called it the "Formative Years". A person's values and outlooks on life are formed very early in life. In turn, these young people will sensitize their parents to conservation issues, and hopefully economic opportunities will improve so that people can't be taken advantage of by the political/ business elite, and most people won't want to take the risks associated with poaching - since they won't have to in order to survive and feed their families!

\section{Project noah}

Tshwane University of Technology (TUT), Dept. of Nature Conservation's Project Noah ${ }^{13}$ [Figure 28] had a program that brought youth from all over rural Africa where wildlife is of value - to study nature conservation at TUT. It was started back in the early 1990s in collaboration with Gilfrid Powys, a well-known Kenyan game rancher and conservationist, and was quickly adopted by the International hunting community, mainly Safari Club International, Dallas Safari Club, Shikar Safari Club \& Mzuri Wildlife Foundation, some safari operators and individuals. It identified youth from rural areas across Sub-Saharan Africa (e.g., Burkina Faso, Cameroon, Kenya,

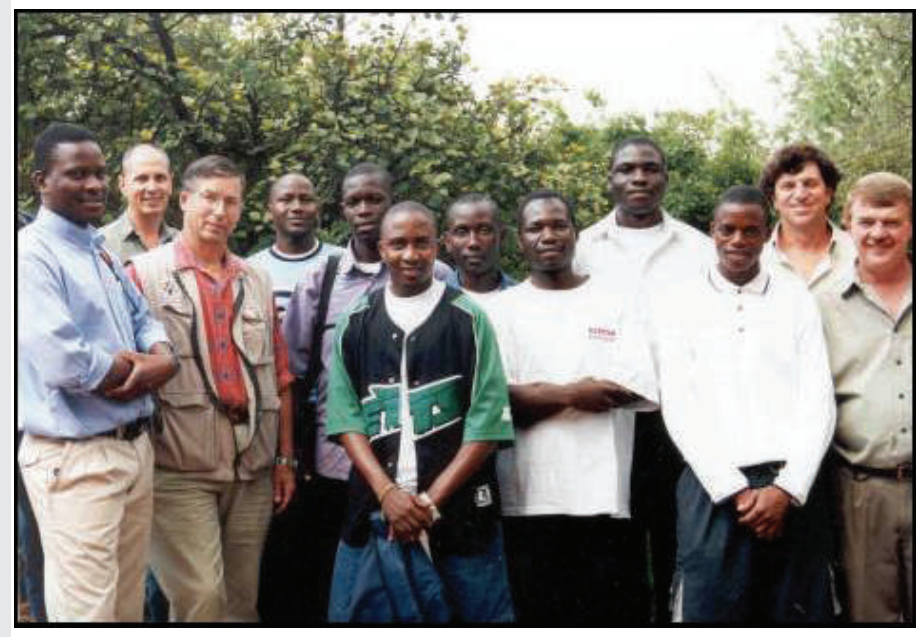

Figure 28: Project Noah Students and Professors at the Department of Nature Conservation, Tshwane University of Technology (TUT) along with a Safari Club International Representative in the mid-2000s. Students pictured include Paulus Arnold a San from Namibia; Maliki Wardjumto a Dowayo from Cameroon's savannas; Armand Biko'o an Mpiemo from the dense humid lowland forests of Southeastern Cameroon; Boipuso "Killer" Mangurunga a Hambukushu \& Matoto Teko a Yei both from the Okavango Delta, Botswana; Joseph Mundawo and Simon Steyn both Shangan from the Chiredzi area of Zimbabwe; and Joel Ole Nyika a Maasai from Kenya. Source Photo: Author.

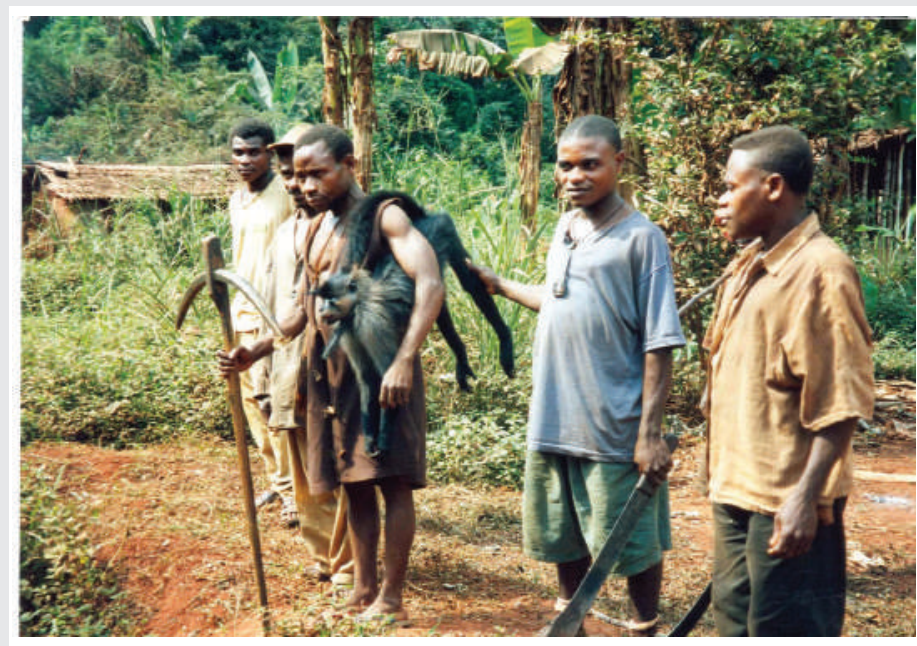

Figure 29: Traditional Natural Historians, Baka Pygmy Hunters, Arbalete/crossbow and poisoned bolts, Southeastern Cameroon, 1990s. Source Photo [1].

Tanzania, Zimbabwe, Botswana, Namibia) where wildlife had a potential to play a major role in conservation and development, and provided them with scholarships.

Students are taught how to manage Africa's grasses and bush, along with its wildlife. A student sent to an American university learns how to manage American vegetation and wildlife, and while the basic principles may be the same, there are big differences in species, climate and especially culture that require different management approaches. This tertiary education must be in Africa by Africans for Africans and their wildlife - not in America or Europe! And besides you can educate 5-10 students in Africa for the cost of one student in America, given how the cost of education has escalated.

This program ran from around 1996 to about 2008, but 
gradually died out as leadership changed within these hunting organizations.

\section{Foreign Aid's potential role in African education}

Think what Foreign Aid could do if pushed in the right direction in one of the resource richest places in the world, but with among the poorest people economically, not culturally!

Even if Project Noah survived, it was a drop in the bucket in the number of students funded, compared to what is needed to educate Africans in Africa by Africans in what is relevant and to avoid the Brain Drain when they are sent overseas and don't want to return. I can't tell you how many times I got in a taxi in the USA to fly back to Africa from Dulles or Ronald Reagan Airports and the driver was an African with a university degree. Says something about what opportunities exist in Africa. I will also never forget in Guyana, a CIA (U.S. Central Intelligence Agency) operative telling me, we identify the best and the brightest from around the World, send them to study in America and keep them there - that's how we make America Great. Education in Africa will stem this hideous practice; my frank opinion! If you steal an educated person from Europe, there will be plenty of educated people to take his/her place. But, if you steal the best and brightest from a Developing Country, you are holding that country back from evolving economically.

The future of Africa and Africa's wildlife is in the hands of you Africans - and I believe properly spent - foreign aid could make a BIG BIG difference - right now it is a form of GLOBAL WELFARE and is holding back Africa just like welfare is holding back our Inner Cities/Concrete Jungles in America.

Masses of youth from these rural areas need to be sent off for tertiary training in forestry, fisheries and wildlife management to run these programs - monitoring offtake in collaboration with traditional natural resource users to assure sustainable management of "THEIR" natural resources, while many others with educational opportunities will chose to become the doctors, lawyers, factory workers and businessmen living in urban settings - thus taking the pressure off these rural areas as less and less people live subsistence lifestyles similar to what happened to the author's Mother's generation of the 20 century.

How many youths have been sent off for tertiary education in wildlife management/nature conservation, and other disciplines in Africa by the Western donors? The amount of money spent in Africa by foreign aid is orders of magnitude more than that generated from hunting, and if properly used could help boost and compliment hunting as a major conservation and development tool integrated into diverse economic activities [e.g., manufacturing - transforming more of Africa's natural resources in Africa as a means of getting added value and creating a middleclass, jump starting community run tourism such as USAID (U.S. Agency for International Development) did with the Rwenzori Mountaineering Service, etc.

I used to ask a good friend and a hunter with the World Bank who was raised in Africa, why there wasn't a major program for such education. He would just shrug his shoulders - basically saying it wasn't in the interest of the World Bank.
Why?? I think you and I know why - the West doesn't want an educated society that might question what is going on, exploitation of Africa's abundant diversity of natural resources by the rest of the World with minimal benefits to Africa and Africans [1]. Look - Intelligence and education are two different things. One is born with intelligence and you get an education. Some of the most intelligent people I have met couldn't read or write, and some of the narrowest thinkers called themselves "Dr."

\section{Taking advantage of traditional knowledge}

Traditional hunters [Figure 29], farmers, fishers, herders, etc. across the globe, many who have not had the opportunity for a formal education, are excellent natural historians and have knowledge as to how to manage their natural resources. Often an ecologist or natural resource management is looking at a window in time, trying to understand what he/she is seeing and what it means. Traditional natural resource users are in the field year-round and have generational knowledge passed on to them by their forefathers. The author has seen where rice farmers around the hypersaline waters of the Casamance, Senegal have had to show the expatriate agronomists how to manage the pyritic soils so as to keep them from drying out, oxidizing and becoming toxic to crops. He has been educated by lobster divers who helped him understand in Belize as to why the virgin coral reefs, he dived in the early 1970 s were dead and dying in the late 1980s/early 1990s. In turn, this helped him understand why he was seeing dead and dying reef off East Africa, the Seychelles and in the Red Sea $[1,10]$. He has hunted with traditional hunters across Africa and been humbled by their knowledge of the bush. In the USA, he has seen watermen share their knowledge of crabs, oysters and water quality with state resource managers. Youth, especially those from rural backgrounds with this generational knowledge, and then formally educated in Africa to manage their wildlife and its habitat can take advantage of this traditional knowledge in making better management decisions!

The advantage of formal education is that it gives one a better idea of the big picture, what is going on beyond one's immediate surroundings, and the courage to speak out and demand change - at least I think, as there are plenty of drones out there being led by the propaganda on the major news networks - such as the African elephant is endangered [Figure 30]. Populations are endangered, not species [1].

So, not only is there a need to push for change as to how these natural areas are managed - by Africans for Africans, but for changing how the millions and millions of dollars of foreign aid are squandered in Africa with little or no impact on the lives of the people or the wildlife.

As Diamond Dealer Trevor Shaw, also of Zulu Nyala Lodge ${ }^{14}$, used to tell the author, "Africa needs a Hand Up, not a Hand Out.

${ }^{14}$ See Zulu Nyala Group, https://zulunyala.co.za/web/home/

Citation: DeGeorges PA (2020) Why Reforming foreign Aid is Critical to the Future of Africa, Africans \& Their Wildlife. Glob J Ecol 5(1): 099-114. 


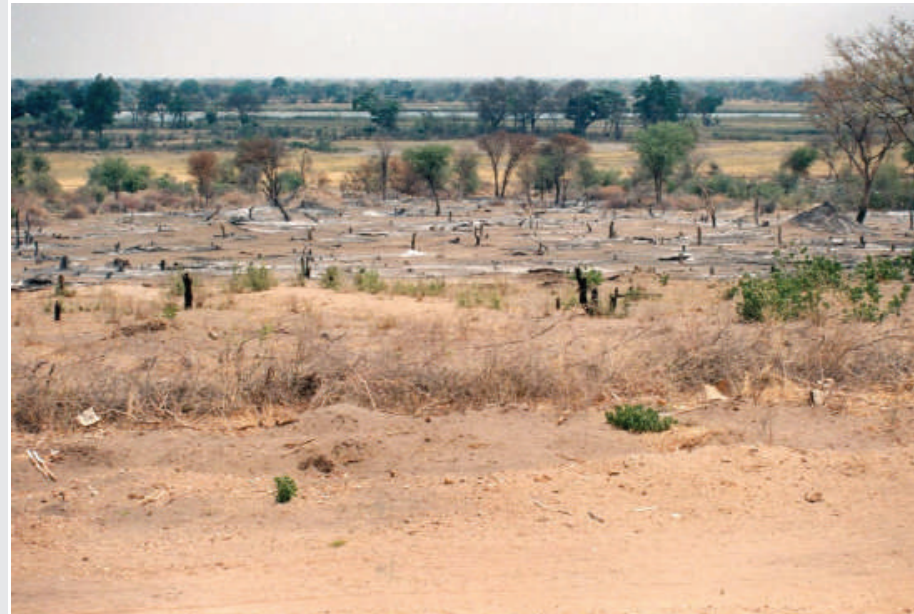

Figure 30: In much of Southern Africa, elephants (Loxodonta africana), which consume up to $250 \mathrm{~kg}$ of food a day/elephant, are over-populated and destroying forested wildlife habitat, especially in Namibia, Botswana, Zimbabwe and South Africa. Elephant Damage, Mahango Game Reserve, Caprivi, Namibia, 1995. Source Photo: [1].

Well right now foreign aid is a Hand Out with minimal impact on the people or the wildlife. Changing how the millions in foreign aid are used could be a Hand Up - Education, Education, Education - and then we would see Africa change just as noted in America during the 20 century when we went from large rural farm families (lots of kids, cheap labor as today in Africa) to better educated urban families of maybe 2 children/family - where children have become consumers as opposed to producers, thus costly and more of a reason to have 2 children instead of 11, as with the author's Mother's generation. Thus, changing how foreign aid is spent could help stem the biggest threat to wildlife - the more than doubling of Sub-Saharan Africa's human population in the next 50 years, and the resulting loss of habitat from people stuck in subsistence lifestyles, and make conservation work for AFRICANS and not the urban yuppies from America \& Europe flooding Sub-Saharan Africa to save Africa's wildlife from you Africans.

\section{How best to use foreign aid as a conservation and deve- lopment tool}

\section{Foreign Aid should be used primarily for:}

1. Early Childhood Nutrition and Health Care - these factors in the early formative years being critical to cognitive abilities,

2. Clean Water

3. Education at all levels (primary, secondary \& tertiary), with conservation integrated into the curricula,

4. Improving trade schools linked to investment in industry,

5. Specific funding of "Project Noah" type programs at the university level in all disciplines in Africa, with rare exceptions of sending people overseas for specialized training usually available in Africa, especially in highly advanced South Africa,

6. Helping link South African universities to universities across Sub-Saharan Africa to help standardize and improve curricula, making education more affordable since students can be educated in the country of their birth.

7. With what is left over should be used to subsidize/jump start Foreign Direct Investment (FDI) in Africa as a means of getting added value from transforming more of Africa's natural resources in Africa, thereby helping to create a large urban middleclass as a means of taking pressure off the rural areas in helping conserve its natural systems.

Having been inside USAID and seen the actions of other donors and the UN (United Nations) in Africa - they are infiltrated just like the USFWS (U.S. Fish \& Wildlife Service) with animal rights/anti-hunting types and NGOs/consulting firms/ so called "Experts" like leeches sucking up money that, as noted, cycles back to America/Europe that could make a real difference if spent in Africa. The author is not a fan of foreign aid as currently practiced - a form of global welfare creating dependency, but if it could be reformed and used as suggested - it could transform Africa and give the people and their wildlife a bright future. Sadly, the author fears that the U.S. \& Europe, along with Africa's political elite, fear an educated society that would no longer accept their Continent being exploited for cheap natural resources. Foreign aid must be revised if Africans and their wildlife are to have a future.

\section{Education through Foreign Aid as a Counter to the Spread of Radical Islam, Necessary for Conservation in Sahelian Countries}

In the case of the Sahelian countries like Cameroon, Burkina Faso, Chad and the Central African Republic where wildlife populations are substantial, as well as Niger, Nigeria, Mali, Mauritania, and Senegal where wildlife is on the decline, and to a lesser degree in Kenya, Tanzania and Mozambique, a key foreign policy issue that people interested in African conservation must pursue is to pressure the U.S. State Department to tell the Saudis/Gulf States - no more sending Wahhabi/Salafi Imams/Marabouts to teach Radical Islam in Africa, and no more sending youth from Africa to madrassas in these countries to be radicalized [11,12].

These youth/Talibs must be educated in Africa and have opportunities to advance economically, and then radicalism - linked to poverty and hopelessness and taken advantage of by the Wahhabi/Salafists - will disappear/diminish. Poverty, rampant corruption, social exclusion, political instability and lack of access to basic services (education and healthcare) have contributed to increasing radicalization of youth in Sub-Saharan Africa [13,14].

Without calm, trying to manage wildlife in these Sahelian/ Saharan countries will be virtually impossible. People in Africa must make it very clear, especially to the U.S. and French 
decisionmakers that there is no long-term military solution to Radical Islam, as they are currently undertaking in the Sahel [1]. The only solutions in the long-term are socio-economic; that is education and economic development!! The problem will not be solved from the Barrel of a Gun!!!

\section{Education as a counter to poaching}

With regards to poaching, as noted bushmeat supplies an important source of protein to rural Africans in both savanna and forest biomes, but needs to be managed sustainably, Figures 31-34.

Given the situation today - for every poacher you capture or kill, if I am some corrupt middleman (politician, businessman, bureaucrat, etc.), I'll find another desperate soul to take his place and give him a gun to kill elephant, rhino or even game for bushmeat. As with Radical Islam, the solutions to poaching are education and economic development. In rural areas, this can occur through integration of traditional hunters/natural resource users into the management of "THEIR" natural resources on "THEIR" traditional lands so they don't have to poach, while empowering them to prevent access to "THEIR"

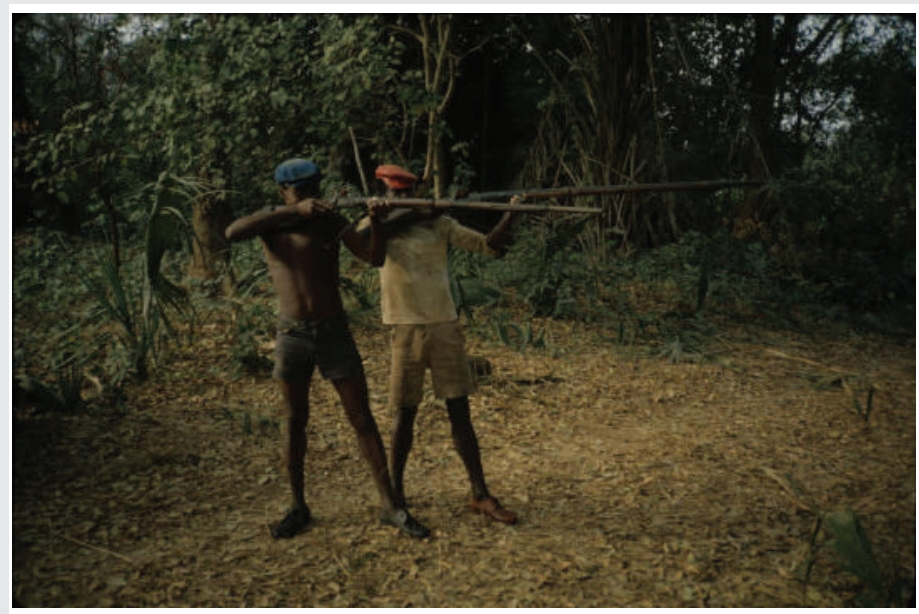

Figure 31: Traditional Hunters, considered poachers by most African Governments and NGOs, with their Fusil de Traite/Trading Musket, Fouta Djallon, Guinea 1980s. Source Photo: Author.

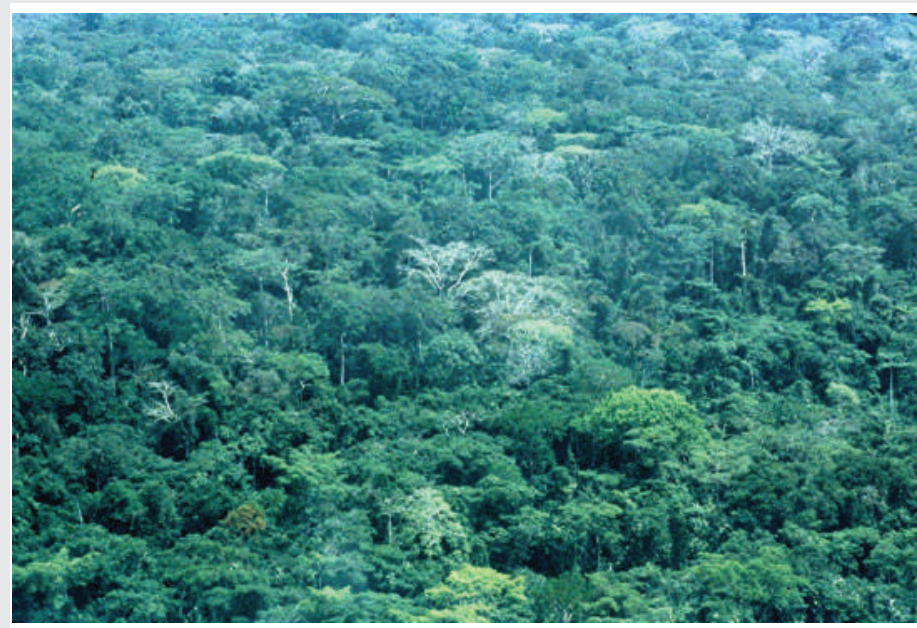

Figure 32: Dense Humid Lowland Forests of the Congo Basin, Southeastern Cameroon, 1990s. Source Photo: Author.
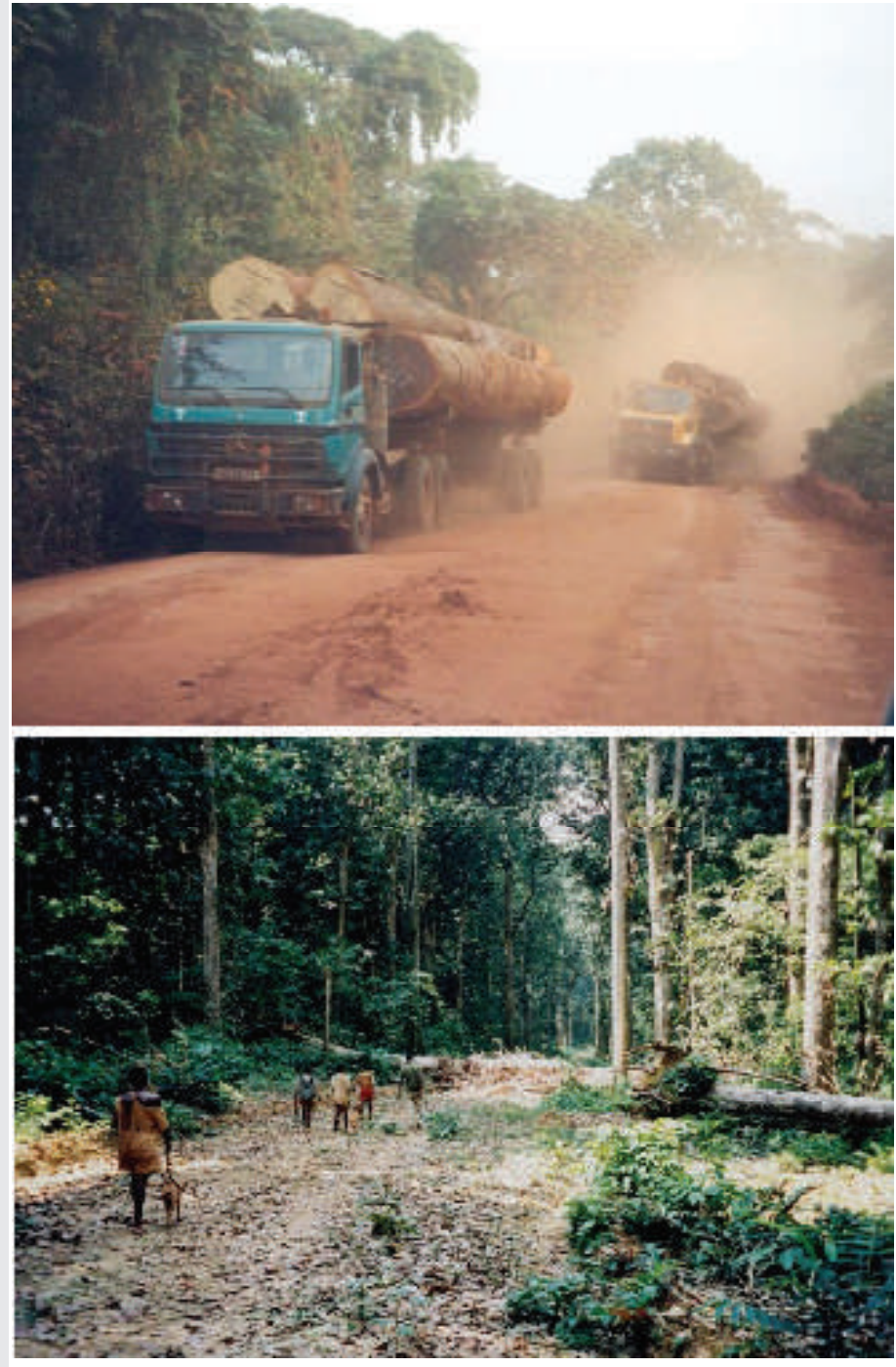

Figure 33,34: Dense Humid Lowland Forests, primarily the domain of the Baka Pygmies, opened up to uncontrolled commercial poaching by commercial logging roads, Southeastern Cameroon, 2000s. Source Photos: [1].

natural resources by noncommunity members. As noted, some youth from these rural areas should be sent off for tertiary training in wildlife management/nature conservation, with signed agreements to return home upon completion of their education to serve as wildlife/natural resource managers for their communities. Simultaneously, pressure must be taken off these rural areas by helping Africa urbanize \& industrialize, thereby creating an urban middleclass. Gun barrel diplomacy is at most a short-term solution, but in the long-term fails $[1,2]$ Figures 35- 37.

Finally, another reason to reform foreign aid, is how it is used to coerce African/Developing Countries into going along, with what are often Western urban biases towards wildlife, as described below. Many of those U.S. delegates at CITES, come out of the U.S. Fish and Wildlife Service (USFWS):

\section{"10.4.3 U.S. Government Threatens African Countries with Foreign Aid Cuts}

In July 1989, 17 African countries met in Gaborone, Botswana, to come up with a unified stance on elephants for

Citation: DeGeorges PA (2020) Why Reforming foreign Aid is Critical to the Future of Africa, Africans \& Their Wildlife. Glob J Ecol 5(1): 099-114. 
CITES. Only five African countries supported the ban, namely Kenya, Tanzania, Ethiopia, Somalia and Zaire. The meeting was dominated by U.S. and European protectionist groups. The U.S. Government subtly threatened both Zimbabwe and Botswana with foreign aid withdrawals if they did not support the ivory ban. They initially refused to accept the Tanzania/Kenya proposals [15 in 1]. Thomson [16 in 1], who attended the 1989 CITES conference, claims that the U.S. delegation threatened all African countries who would vote against placing elephants on CITES I with foreign aid cuts.

Duffy [17 in 1] explains that northern states threatened cuts in foreign aid for states that supported Zimbabwe, Botswana and Namibia's request for trade in ivory, while only supporting trade if there was a common African policy on ivory trade, but making the achievement of this goal very difficult if not impossible. The French have made similar threats to

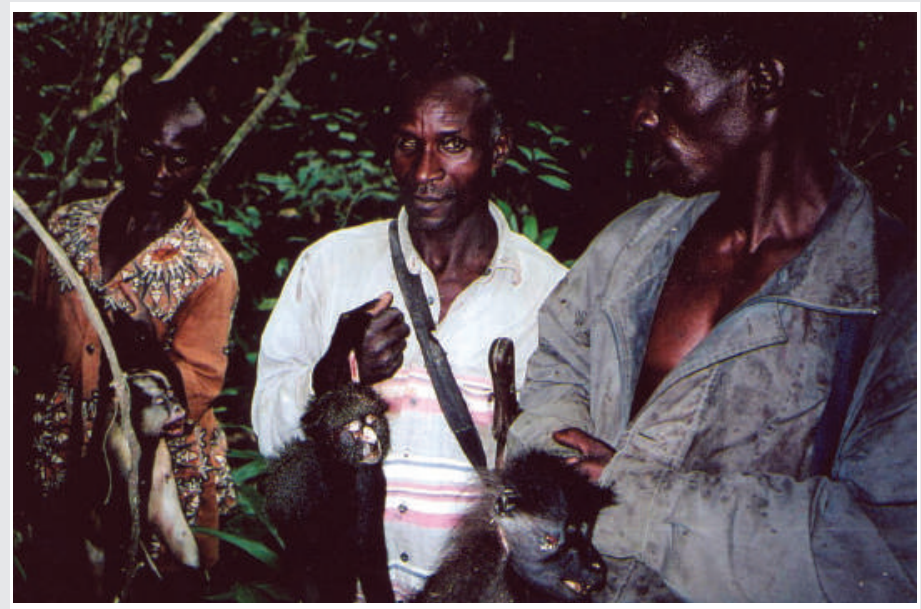

Figure 35: Traditional Tikar hunters, village of Kong, Central Cameroon, just north of the old German capital of Yoko, in transition area between forest and savanna, 2005. This community already considers a portion of the forest theirs, based upon tradition, and control who, how, when and what can be hunted. Source Photo: [1].

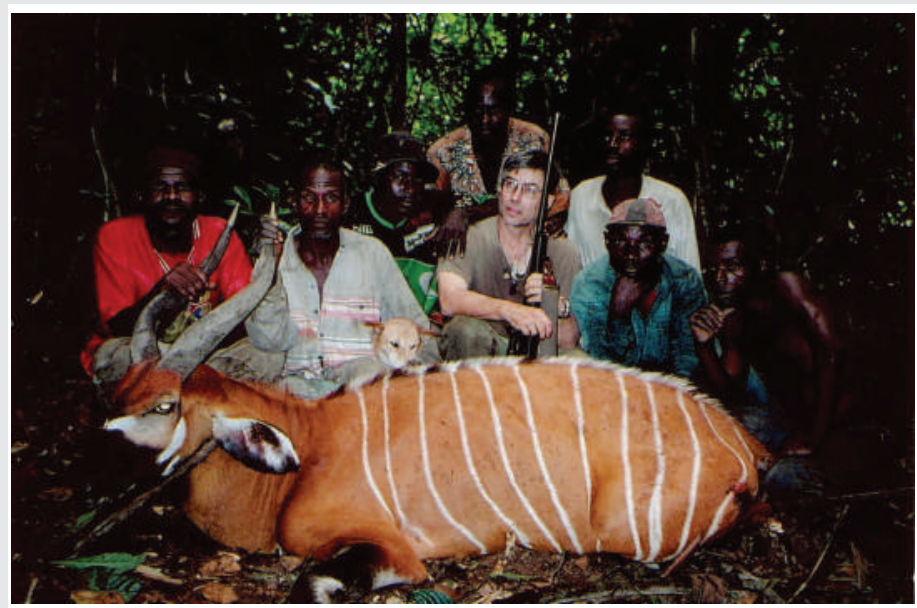

Figure 36: Trophy Hunting employs many people from rural Africa, is important in providing development opportunities for rural communities, and provides the budget for the operation of many game departments. Bongo (Tragelaphus eurycerus) taken with Tikar Hunters, village of Kong, just north of the old German capital Yoko, Southeastern Cameroon, 2005. Note Basenji, one of the oldest breeds of domesticated dogs in the world, originating from Central Africa and depicted on paintings in Egyptian pyramids. The "voiceless dog" is prized for its hunting skills. Source Photo: [1].

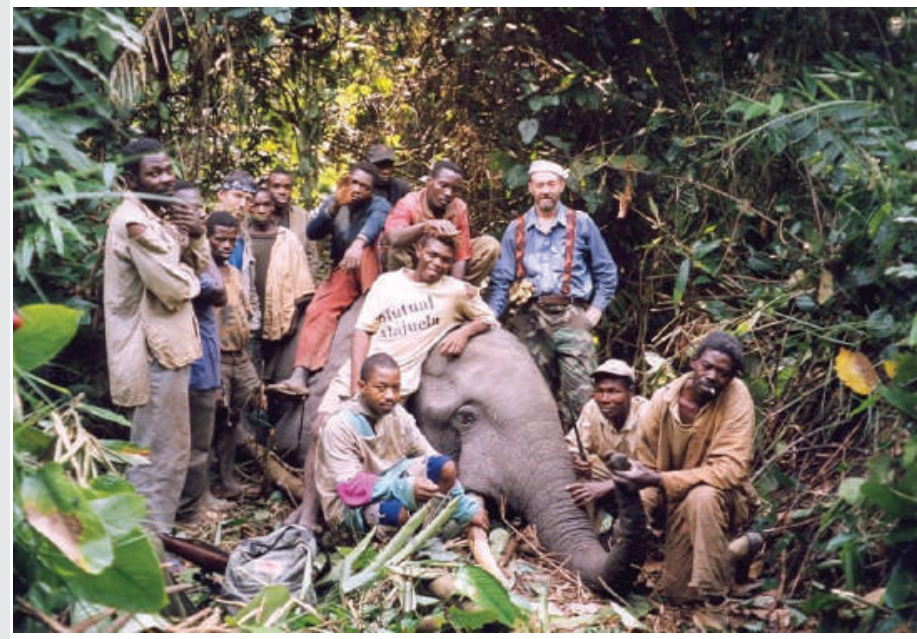

Figure 37: Forest Elephant (Loxodonta cyclotis) taken on self-guided hunt with Baka Pygmies \& Maka Hunters, Zoulabot II, south of the Dja River, Cameroon, 2000. Note - taken on internationally recognized CITES quota, trophies legally imported into South Africa, but USFWS said it could never be imported into America. Source Photo: [1]

their former colonies at COPs 10 and 11 (Francophone Africa Delegates to CITES COP 10 and 11, pers. comm $)^{15 "}$ [1].

Also, with regards to the Francophone countries, France controls/manipulates local currencies, originally pegged to the French franc at a rate of fifty CFA (Central \& West African francs) francs to one French franc (since 1994 devalued at 100/1) [1] with each Francophone African country handing over 50$65 \%$ of its foreign reserves to the French Treasury depending upon the region [18]. Such manipulations help the West obtain cheap natural resources, while making products imported into the Developing World more expensive. The devaluation of the CFA at 100/1 has had a devastating impact on wildlife in many countries (e.g., Cameroon), people turning to poaching as other segments of the economy collapsed [1]. These kinds of manipulations of African economies by the West, adversely impact upon wildlife, the people and their economies. In recent days there has been some talk of the Economic Community of West African States (ECOWAS) consisting of Benin, Burkina Faso, Guinea-Bissau, Ivory Coast, Mali, Niger, Senegal and Togo going from the West African CFA to a new currency, the Eco, with France no longer holding the foreign reserves in the French Treasury and withdrawal of French governance related to the currency [19].

The funding of environmental assessments of dams through foreign aid by Western donors have been disastrous $[1,20]$ or potentially disastrous $[1,21]$ for both natural systems and associated wildlife, along with traditional agricultural production systems. This should not be allowed to happen.

The author doesn't claim to have all the answers, but he can see many shortcomings. He can only encourage people

${ }^{15}$ Issah Djoh N'Diang, then Deputy Director of Wildlife, MINEF, Yaounde, Cameroon and Dominique Ngonba Ngouadakpa Director of Wildlife, Direction de la faune et des Resources Halieutiques, BP 830, Bangui, RCA 
in influential positions in conservation to push the Western donors [e.g., World Bank, IMF (International Monetary Fund), USAID, CIDA (Canadian International Development Agency), AFD (French Development Agency), GTZ (German Development Agency), etc.] to stop manipulating Africa's economies and politics to their advantage and start helping Africa on to a valid road to development. China is coming in and if allowed will likely do the same, but the author has the impression that they are outcompeting the Yanks and Europeans - putting in infrastructure and undertaking some transformation of raw natural resources in Africa. Also, as noted, we don't need to be militarizing Africa. That won't be necessary if Africa evolves economically and there is a large middleclass. Then both the people and the wildlife will have a future.

If foreign aid is not reformed so actual economic development results in a more urbanized middleclass, as a means of taking pressure off rural areas and Africa's wildlife/ habitat, not only will Africa suffer, but Europe will see a flood of poverty coming out of Africa that could also overwhelm Europe. Though not specifically about Africa, the racist book The Camp of the Saints [22] predicted mass migrations of the poor from the Developing World into the Developed World; something we are seeing across the globe. Europe needs a wakeup call. No one wants to leave their family, culture, birth place, but as one young Salvadorian told the author as a Peace Corps Volunteer in the 1970 s when he was studying the ecology of its lakes, "When the ship sinks, the rats will swim. I'm getting the hell out of here, going to the Promised Land, your country. I'll share a room with 5 or 6 other guys, send money home to my folks and if I get caught, they don't put me in prison, nope, I get sent on a paid vacation back to El Salvador to visit friends/ family and I'll be back in the U.S. within a couple of months"! Europe WAKEUP, the future of Africa will have a major impact on the future of Europe, positive or negative depending on what happens in Africa, and the same goes for South Africa that is also experiencing similar immigrations.

Most importantly, if people in positions of influence, just push the very important and successful CBNRM (Community Based Natural Resource Management) on its own, without pushing for MAJOR changes in how FOREIGN AID is used in Sub-Saharan Africa, as described in this policy document, they are like the little Dutch Boy with his finger plugging the hole in the dyke. They may be able to stop the flood of humanity for a few years but by 2050 if not sooner the flood will overcome you and your goals - conservation of Africa's wildlife and more importantly improving the lives of its citizens. YOU in Positions of Influence can make a difference.

Those Africans with Global Contacts can push for change in how foreign aid is deployed and give Africans and THEIR wildlife a bright future in the 21 Century. The author is positive on that!

\section{Conclusion}

Foreign aid as currently deployed benefits the Developed World more than Africa/The Developing World, with very little benefit reaching the poorest of the poor. While in Southern
Africa there has been some benefit from foreign aid in support of Community Based Natural Resource Management (CBNRM) that provides some economic benefits to rural communities, due to capture of net profits by other stakeholders (e.g., governments and safari operators) and due to the low resource to population ratio, benefits tend to be insignificant at the household level, community income tending to be used for common property benefits (e.g., schools, clinics, boreholes, etc.). While these benefits are important, due to the expected more than doubling of the human population in the next 50 years, with the majority stuck in poverty/subsistence lifestyles, unless there are drastic changes, the future of Africa's revered mega-fauna and its habitat are in jeopardy. This policy document is based upon the author's personal experiences over a 30-year period, advising African governments, USAID, the safari industry and academia. It attempts to illustrate key conservation and development issues both in words and unique photographs. It demonstrates that there is a crying need for reform of foreign aid, with a major emphasis on education from primary through tertiary education, in Africa, by Africans to train youth in all disciplines, but in the case of conservation with an emphasis on training in wildlife/natural resource management that links generational traditional knowledge with Western concepts of wildlife/habitat management adapted to Africa by Africans in African universities. This will help stem the brain drain, integrate traditional natural resource users into the management of "THEIR" natural resources, and can even be used to help prevent impoverished youth from being recruited into Radical Islam. This emphasis on education should be combined with clean water, early childhood health care critical for cognitive abilities, and helping increase Foreign Direct Investment (FDI) to transform more of Africa incredible wealth of natural resources in Africa. The investment of foreign aid in these activities will help create an urban middleclass, decrease family size and decrease pressure of surviving off the ever-decreasing wildlife, forests, fisheries and related habitats. If this path is followed, Africa, African and "THEIR" wildlife will have a bright future, Inshallah!

\section{Acknowledgements}

The author would like to thank the people of Africa from the traditional hunters/natural resources, safari operators/ professional hunters, and his professional colleagues in the OMVG and at TUT for adopting him, giving him a home and educating him as to what is required for Africa, Africans and "THEIR" wildlife to have a viable future. May God Bless you all!

\section{About the author}

Dr. DeGeorges has over 30 years of experience in natural resource management, planning and policy reform in Africa, the Caribbean, Central America and the United States. He retired from the Department of Nature Conservation, Tshwane University of Technology (TUT), Pretoria, South Africa in 2008. From 1994 until November 2001, he represented about 30,000 international hunters, opening the first overseas operation of Safari Club International (SCI), serving as Manager of the SCI Africa Office on the continent with the world's most diverse mega-fauna. He served as Environmental Advisor to 
the Gambia River Basin Development Organization (OMVG) from 1982-1988, whose member states were Senegal, Gambia, Guinea Conakry and Guinea Bissau, was USAID/LAC's Regional Environmental Management Specialist (REMS) to the Caribbean, and USAID/REDSO/ESA's Regional Environmental Management Specialist in East and Southern Africa. $\mathrm{He}$ worked two years for the U.S. Environmental Protection Agency (USEPA) in the largest unprotected wetland in America, the Atchafalaya River Basin, Louisiana, whose unique Cyprus and Tupelo swamps are critical to the Cajun culture and the crawfishing and sportfishing industries. He spent another $4 \& 1 / 2$ years undertaking environmental impact statements (EIS's) for the USEPA on a contractual basis with a consulting firm. As a U.S. Peace Corps Volunteer, he studied the limnology of El Salvador's lakes and helped the State of Louisiana develop a conservation exchange program with El Salvador under the "Partners in the America's Program."

\section{References}

1. DeGeorges PA, Reilly BK (2008) A critical evaluation of conservation and development in Sub-Saharan Africa: Last Chance Africa. Edwin Mellen Press, Lewiston, New York. 7 books, 3: 572. Link: https://bit.ly/3/43bFb

2. DeGeorges PA, Reilly BK (2009) The realities of community based natura resource management and biodiversity conservation in Sub-Saharan Africa. Sustainability 1: 734-788. Link: https://bit.ly/2Gzwa4Q

3. Ogwang DA, DeGeorges PA (1992) Draft Final. Community participation in interactive park planning and the privatization process in Uganda's National Parks. Prepared for Uganda National Parks and the United States Agency for International Development 86.

4. DeGeorges PA (1992) ADMADE. An evaluation. Today and the future. Policy issues and direction. Prepared for USAID/Lusaka and the National Parks and Wildlife Service of Zambia. 79.

5. Sowry R (2020) The real threat to wildlife - The facts from a game ranger. SA Jagters 28-34.

6. Thomson R (2000) Personal communication over many years while living in Africa.

7. Mantheakis M (2020) Chairman of Tanzania Hunting Operators Association (TAHOA). Feb. 17, 2020 email to author giving permission to use statistics provided by him in YouTube videos and previous emails to author.

8. Beard P (1988) The end of the game. Chronicle Books, San Francisco, CA 230

9. Maliti HT (2003) The use of GIS as a tool in wildlife monitoring in Tanzania Proposal, Master's Degree, Tshwane University of Technology: Pretoria, South Africa. Technical Officer (Tanzania Wildlife Conservation Monitoring - TWCM), Arusha.

10. DeGeorges A, Goreau TJ, Reilly BK (2010) Land-sourced pollution with an emphasis on domestic sewage: Lessons from the Caribbean and implications for coastal development on Indian Ocean and Pacific coral reefs. Sustainability 2: 2919-2949. Link: https://bit.ly/366Pq2r

11. Heungoup $\mathrm{H}$, de $\mathrm{M}$ (2015) Radicalisme religieux: quel attrait sur les jeunes? Grain de sel. No. 71. Link: https://bit.ly/2U3ohrf

12. Solomon S (2017) As Africa Faces More Terrorism, Experts Point to Saudispread of Fundamentalist Islam. Link: https://bit.ly/38ZOnV2
13. Faleg G (2019) Conflict in Mozambique. Can there be peace after the storm. European Union Institute for Security Studies (ISS), Brief 5: 8. Link: https://bit.ly/2Gzv49e

14. Sukhankin S (2020) Terrorist Threat as a Pre-Text: Russia Strengthens Ties with G5 Sahel. The Jamestown Foundation, Terrorism Monitor 18: 5-6. Link: https://bit.ly/3mWrYf6

15. Bonner R (1993) At the hand of man. Peril and hope for Africa's wildlife Alfred A. Knopf: New York. 322. Link: https://bit.ly/34XXW4q

16. Thomson R (2003) A game warden's report. The state of wildlife in Africa at the start of the third millennium. Magron Publishers: Hartbeespoort, South Africa 416. Link: https://bit.ly/3k1xtqL

17. Duffy R (2000) Killing for conservation. Wildlife policy in Zimbabwe. African Issues. The International African Institute in association with James Currey Oxford, Indiana University Press, Bloomington \& Indianapolis and Weaver, Harare. 209. Link: https://bit.ly/2TYmX9m

18. Franc Zone (2019) France Diplomatie, Ministry for Europe and Foreign Affairs. Link: https://bit.ly/350abgU

19. Fröhlich S (2019) West Africa's new currency, the Eco: Rebrand or fresh start? Deutsche Welle (DW).https://bit.ly/3n7U6Mr

20. DeGeorges PA, Reilly BK (2006) Dams and large-scale irrigation on the Senegal River: Impacts on man and the environment. International Journal of Environmental Studies 63: 633-644. Link: https://bit.ly/3k18sfB

21. DeGeorges PA, Reilly BK (2007) Eco-politics of dams on the Gambia River International Journal of Water Resources Development 23: 641-657. Link: https://bit.ly/3mS9mN6

22. Raspail J (1975) The camp of the saints. Charles Scribner's Sons. 311. Link: https://bit.ly/3oZ7B2q

\section{Discover a bigger Impact and Visibility of your article publication with} Peertechz Publications

\section{Highlights}

* Signatory publisher of ORCID

* Signatory Publisher of DORA (San Francisco Declaration on Research Assessment)

* Articles archived in worlds' renowned service providers such as Portico, CNKI, AGRIS TDNet, Base (Bielefeld University Library), CrossRef, Scilit, J-Gate etc.

* Journals indexed in ICMJE, SHERPA/ROMEO, Google Scholar etc.

* OAI-PMH (Open Archives Initiative Protocol for Metadata Harvesting)

* Dedicated Editorial Board for every journal

* Accurate and rapid peer-review process

* Increased citations of published articles through promotions

* Reduced timeline for article publication

Submit your articles and experience a new surge in publication services (https://www.peertechz.com/submission).

Peertechz journals wishes everlasting success in your every endeavours.

Copyright: @ 2020 DeGeorges PA, et al. This is an open-access article distributed under the terms of the Creative Commons Attribution License, which permits unrestricted use, distribution, and reproduction in any medium, provided the original author and source are credited.

Citation: DeGeorges PA (2020) Why Reforming foreign Aid is Critical to the Future of Africa, Africans \& Their Wildlife. Glob J Ecol 5(1): 099-114. DOI: https://dx.doi.org/10.17352/gje.000028 